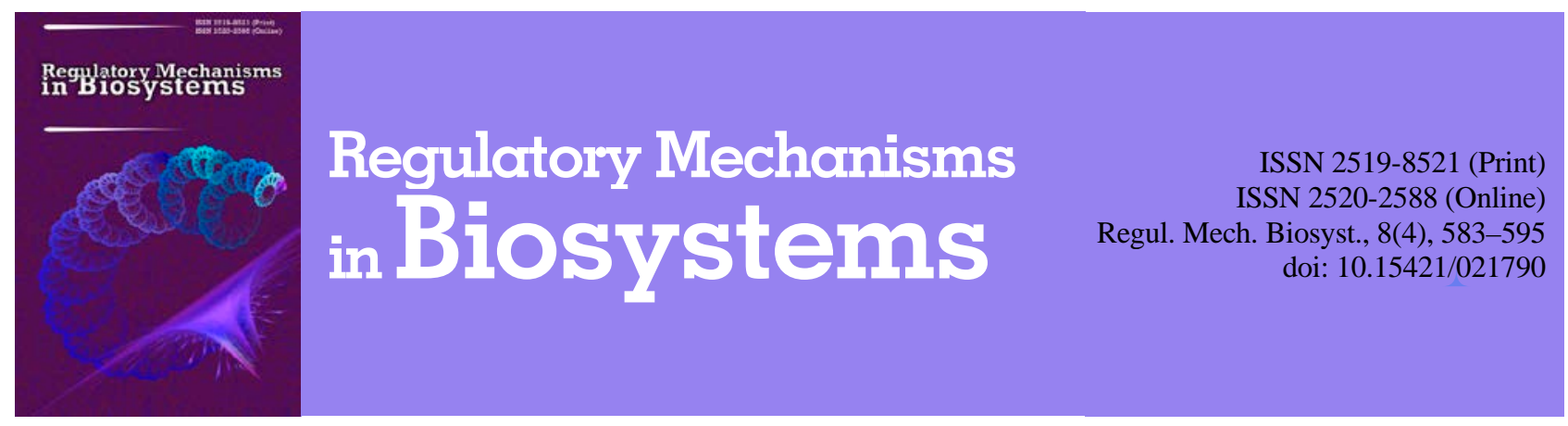

\title{
Levosalbutamol as alternative to drugs on the basis of racemic salbutamol: Review of the results of pre-clinical research
}

\author{
A. G. Miroshnichenko, Y. S. Bulgakova, V. Y. Perfiliev, N. G. Bazarnova
}

Altai State University, Barnaul, Russia

Article info

Received 10.10.2017

Received in revised form

14.11.2017

Accepted 17.11.2017

Altai State University, Lenin ave., 61,

Barnaul, 656049,

Russian Federation.

Tel.: +7-385-229-12-09.

E-mail ag.miro@yandex.ru
Miroshnichenko, A. G., Bulgakova, Y. S., Perfiliev, V. Y., \& Bazarnova, N. G. (2017). Levosalbutamol as alternative to drugs on the basis of racemic salbutamol: Review of the results of pre-clinical research. Regulatory Mechanisms in Biosystems, 8(4), 583-595. doi:10.15421/021790

The aim of the work is to conduct an analytical review of the results of preclinical studies of levosalbutamol. The review discusses the pharmacodynamic features of the R-stereoisomer of salbutamol in vitro. The chemical bases of interaction of levosalbutamol with $\beta_{2}$-adrenoreceptors, intracellular signaling cascades associated with $\beta_{2}$-adrenoreceptors, and structural features of clinically significant ligands of $\beta_{2}$-adrenoreceptors are presented. Broncholytic activity, influence on the contractility of the diaphragmatic muscles, mucociliary clearance of R-salbutamol in comparison with racemic salbutamol are described. The data presented indicate that all known $\beta_{2}$-adrenergic receptor-dependent effects of racemic salbutamol, including bronchodilation, are realized by its R-enantiomer. There is evidence that the regular inhalation administration of racemic salbutamol is accompanied by a partial decrease in the bronchoprotective effect and an increase in airway hyperreactivity in response to the action of provocative factors. It was found that the development of hyperreactivity of the respiratory tract is excluded in the case of regular inhalation of levosalbutamol. Possible mechanisms of the paradoxical bronchoconstrictor effect of the salbutamol dystomer are described. This article shows the beneficial effect of levosalbutamol on mucociliary clearance, its anti-inflammatory activity and antiallergic effect. The image data are compared between the enantiomers and the racemate of salbutamol. Special attention is paid to the pharmacokinetics of enantiomers of salbutamol. The data presented from the preclinical studies provide evidence of chiral inversion of stereoisomers of salbutamol.

Keywords: R-salbutamol; $\beta_{2}$-agonist; chirality; enantioselectivity; pharmacodynamics

\section{Левосальбутамол как альтернатива лекарственным препаратам на основе рацемического сальбутамола: обзор результатов доклинических исследований}

\author{
А. Г. Мирошниченко, Я. С. Булгакова, В. Ю. Перфильев, Н. Г. Базарнова
}

Алтайский государственный университет, Барнаул, Россия

Проанализированы результаты доклинических исследований лекарственного средства левосальбутамол. Обсуждаются фармакодинамические особенности R-стереоизомера сальбутамола in vitro. Представлены химические основы взаимодействия левосальбутамола с $\beta_{2}$-адренорецепторами, внутриклеточные сигнальные каскады, ассоциированные с $\beta_{2}$-адренорецепторами, а также структурные особенности клинически значимых лигандов $\beta_{2}$-адренорецепторов. Описана бронхолитическая активность, влияние на контрактильность диафрагмальных мышщ, мукоцилиарный клиренс R-сальбутамола по сравнению с рацемическим сальбутамолом. Приведены данные, которые указывают на то, что все известные $\beta_{2}$-адренорецепторзависимые эффекты рацемического сальбутамола, включая бронходилатацию, реализуются за счет его R-энантиомера. Имеются свидетельства того, что регулярное ингаляционное введение рацемического сальбутамола сопровождается парциальным снижением бронхопротективного эффекта и увеличением гиперреактивности дыхательных путей в ответ на действие провокационных факторов. При этом развитие гиперреактивности дыхательных путей исключено в случае регулярного ингаляционного введения левосальбутамола. Описаны возможные механизмы парадоксального бронхоконстрикторного действия дистомера сальбутамола. Отмечено благоприятное влияние левосальбутамола на мукоцилиарный клиренс, его противовоспалительная активность и антиаллергическое действие. Данные эффекты сравниваются между энантиомерами и рацематом сальбутамола. Отдельное внимание уделено фармакокинетике энантиомеров сальбутамола. Представлены данные доклинических исследований, свидетельствующие о хиральной инверсии стереоизомеров сальбутамола.

Ключевые слова: R-сальбутамол; $\beta_{2}$-агонист; энантиоселективность; фармакокинетика; фармакодинамика

\section{Введение}

Значительное число синтетических лекарственных средств, доступных в настоящее время для клинического применения, раз- работано на основе фармакологически активных субстанций, молекулы которых включают, как минимум, один хиральный центр (Calcaterra and D’Acquarica, 2017), представленный в большинстве случаев асимметричным атомом углерода. Присутствие таких 
атомов обусловливает способность молекул одного и того же вещества к разнонаправленному вращению в плоскополяризованном свете и формированию право- и левовращающих оптических изомеров, называемых S- и R-энантиомерами, соответственно. Таким образом, энантиомеры - оптические изомеры молекул вещества, характеризующиеся наличием идентичной молекулярной формулы, сходными характеристиками межатомных взаимодействий, аналогичными физическими и химическими свойствами, но обладающие отличной пространственной конфигурацией, обусловленной различием их оптической активности. Эквимолярные смеси (50/50) S- и R-энантиомеров веществ, лишенные оптической активности, получили название рацемических.

В настоящее время молекулярная стереохимия является одним из фундаментальных направлений в сфере поиска и разработки лекарственных средств. Изучение хиральных свойств фармакологически активных субстанций обеспечивает глубокое понимание механизмов их взаимодействия с биологическими мишенями (Zhang et al., 2005), что, в свою очередь, ассоциируется с увеличением эффективности поиска «лидеров» с сопутствующим снижением риска неудач на промежуточных этапах разработки лекарственных средств. По данным анализа причин досрочного прекращения клинических исследований II/III фазы впервые предлагаемых лекарственных средств и лекарственных средств, предлагаемых по новым показаниям, почти в трети случаев являлось несоответствие исходов фармакотерапии критериям эффективности (Arrowsmith, 2011).

Эффекты фармакологически активных субстанций реализуются путем их взаимодействия с биологическими мишенями, в качестве которых в случае применения низкомолекулярных веществ выступают, главным образом, протеины, принадлежащие к семействам энзимов, экстраклеточных и ядерных рецепторов (транскрипционных факторов), ионных каналов, транспортных протеинов, и, конечно, рецепторы, ассоциированные c G-протеинами. Последние являются главной молекулярной мишенью фармакологических эффектов антигипертензивных и противоаллергических средств (Gashaw et al., 2012). Взаимодействия лекарственных веществ с таргетными протеинами имитируют динамику связывания эндогенных лигандов с активными сайтами этих протеинов, нередко называемых в литературе «карманами» (binding pockets). Такие карманы формируются определенными последовательностями аминокислотных остатков и детерминируются их физико-химическими характеристиками, что определяет структуру, локализацию и функциональность сайтов связывания с лигандом (Stank et al., 2016).

В настоящее время уже не подвергается сомнению, что эффективность взаимодействия с биологической макромолекулой - мишенью детерминируется геометрическим соответствием молекулы лиганда и активного сайта, то есть их комплементарностью (Kubinyi, 2003). Аминокислоты, за исключением глицина, характеризуются хиральными свойствами, в связи с чем активные сайты связывания в составе протеинов являются асимметричными, а значит, помимо комлементарности, важным условием эффективного взаимодействия с лигандом, обладающим хиральными свойствами, является пространственная конфигурация его энантиомеров. Последняя, в свою очередь, определяет существенные различия аффинитета связывания R- и S-энантиомеров хиральных лекарственных субстанций (Burke and Henderson, 2002; Kubinyi, 2003) и лежит в основе феномена энантиоселективности их фармакокинетики или фармакодинамики (Barnette et al., 2017; Kuchay and Mithal, 2017; Noguchi et al., 2017; Välitalo et al., 2017). Удаление из лекарственного препарата энантиомера, лишенного фармакологической активности или обладающего неоптимальными фармакодинамическими или фармакокинетическими свойствами, может ассоциироваться с повышением клинической эффективности лекарственных средств, в том числе ранее одобренных для клинического применения, минимизировать фармакодинамическую и фармакокинетическую вариабельность ответов на лечение и, возможно, снизить вероятность развития нежелатель- ных событий, ассоциированных с фармакотерапией рацематами.

В настоящее время в фармацевтической индустрии распространен термин «racemic switch», обозначающий процесс вытеснения ранее одобренных лекарственных средств на основе рацематов их энантиомерно чистыми «аналогами» (Milgrom, 2006). Фактически процесс такого вытеснения может квалифицироваться как один из способов расширения перечня инновационных лекарственных препаратов (Blin, 2004), во многом ставший возможным для реализации за счет все большей доступности высокочувствительных методов энантиосепарации и молекулярного моделирования, базирующихся на хиральных различиях энантиомеров и энергии их связывания с полимерными селекторами, чаще всего представленными дериватами $\beta$-декстрина или энантиомер-селективными протеинами (Liu et al., 2016; Gutierrez-Climente, et al., 2017; Li et al., 2017; Sardella et al., 2017). Между тем, при рассмотрении вопроса о целесообразности такого вытеснения критически важно оценить не только выполнимость процесса получения интересующей энантиомерно чистой фармакологически активной субстанции и наличие маркетинговых преимуществ лекарственного средства на ее основе, но и наличие клинических преимуществ в сравнении с рацемическим «прототипом» (Milgrom, 2006), тем более, что к настоящему времени в научных публикациях приводятся примеры, указывающие на отсутствие таковых (Gaskell et al., 2017). Таким образом, не вызывает сомнения тот факт, что критически важным этапом в разработке таких лекарственных средств должна являться взвешенная объективная оценка их фармакокинетики, эффективности и безопасности в рамках хорошо спланированных доклинических и клинических исследований с применением современных валидированных научных методов по сравнению с референтными (рацемическими) лекарственными препаратами.

Бронходилататоры - терапевтические агенты, широко применяемые с целью терапии пациентов с бронхиальной астмой и хронической обструктивной болезнью легких (ХОБЛ). Расширение бронхов достигается, в первую очередь, посредством локального повышения активности симпатической нервной системы в бронхах, то есть активацией $\beta_{2}$-адренорецепторов, либо подавлением парасимпатических влияний на фоне блокады М-холинергических рецепторов. На протяжении последних двадцати лет общая концепция механизмов реализации бронхолитического действия не менялась (Günay et al., 2016). Между тем, в качестве адъювантной фармакологической активности рассматривается потенциальное противовоспалительное действие, обусловленное стабилизацией тучных клеток и подавлением их дегрануляции с выбросом провоспалительных и бронхоконстрикторных медиаторов. Другие потенциальные эффекты включают улучшение мукоцилиарного клиренса и подавление экстравазации протеинов плазмы крови, лежащей в основе экссудации и отека (Broadley, 2006).

Агонисты $\beta_{2}$-адренорецепторы, такие как сальбутамол, тербуталин, а также их аналоги длительного действия сальмотерол и формотерол являются хиральными агентами и традиционно производятся в форме рацемических смесей, включающих фармакологически активный эутомер и неактивный дистомер. Несмотря на очевидный терапевтический потенциал и широкое клиническое применение, применение $\beta_{2}$-агонистов довольно противоречиво и ассоциируется с увеличением риска смертности в популяции пациентов с бронхообструктивными заболеваниями, ухудшением контроля заболевания, причины которого остаются в высшей степени трудны для понимания. В качестве клинического аспекта фармакологии $\beta_{2}$-адренорецепторов признано значение генетического полиморфизма рецепторов и его возможная связь с развитием толерантности к бронходилатации. Противоречивость применения $\beta_{2}$-адреномиметиков усиливается их стереоизомеризмом и присутствием в составе всех доступных в настоящее время препаратов агонистов $\beta_{2}$-адренорецепторов фармакологически неактивного S-энантиомеров, обладающих потенциально неблагоприят- 
ными эффектами (Broadley, 2006). Токсичность, присущая дистомерам $\beta_{2}$-адренорецепторов, активно обсуждается, что является триггером вытеснения рацемических препаратов агонистов $\beta_{2}$-адренорецепторов препаратами энантиомерно чистых субстанций. Этот процесс достиг своей кульминации в разработке и активном внедрении в клиническую практику, начиная с конца 1990-х годов препаратов на основе левовращающего изомера сальбутамола - левосальбутамола (Boulton and Fawcett, 2002; Jantikar et al., 2007), презентируемого в качестве альтернативного эффективного и безопасного терапевтического средства для лечения пациентов с бронхиальной астмой и ХОБЛ (Nowak, 2003). Berger (2003) опубликовал обзор по данным оригинальных публикаций в рецензируемых журналах, результатов профессиональных обсуждений, а также информации, представленной производителем препарата Хopenex ${ }^{\circledR}$ (Sepracor Inc., США), с целью обоснования применения левосальбутамола в лечении взрослых пациентов и детей с бронхиальной астмой. Автором показано, что по сравнению с рацематом левосальбутамол обладает преимуществами по эффективности и безопасности у пациентов, страдающих бронхиальной астмой, а также характеризуется позитивным балансом «затраты эффективность». Однако, по мнению Berger (2003), требуются дополнительные научные доказательства преимуществ левосальбутамола при бронхообструктивных заболеваниях. Таким образом, целью настоящего обзора является представление результатов доклинических исследований специфической фармакологической активности и фармакокинетики левосальбутамола in vitro по сравнению с сальбутамолом, являющихся важнейшим этапом разработки лекарственных средств в контексте их прогностического значения для оценки эффективности у человека.

\section{Фармакодинамика}

Взаимодействие с $\boldsymbol{\beta}_{2}$-адренорецепторами. У животных и человека бронхоконстрикция устраняется R-эпинефрином, продуцируемым мозговым веществом надпочечников (Handley, 1999; Page and Morley, 1999; Ameredes and Calhoun, 2006). Moлекулярной мишенью бронходилатирующего действия R-эпинефрина являются $\beta_{2}$-адренорецепторы, составляющие около $70 \%$ всей популяции $\beta$-адренорецепторов в легких. $\beta_{2}$-Адренорецепторы экспрессируются в гладкомышечных клетках дыхательных путей (главным образом, мелких), эпителиоцитах, гладкомышечных стенках сосудов и субмукозных железах. $\beta_{2}$-Адренорецепторы детектируются во многих провоспалительных и иммунных клетках, в том числе макрофагах, нейтрофилах, лимфоцитах, эозинофилах, тучных и альвеолярных клетках I и II типов. $\beta_{2}$-Адренорецепторы относятся к крупному семейству серпентинных, или 7ТМ-трансмембранных рецепторов, $\alpha$-спираль которых ассоциирована с G-протеинами. 413-аминокислотная последовательность $\alpha$-спирали $\beta_{2}$-адренорецепторов имеет большое значение для эффективного связывания с их физиологическим лигандом R-эпинефрином. В частности установлено, что эссенциальные аминокислотные остатки, необходимые для высокоаффинного связывания рецептора с лигандом, локализованы внутри третьей (Asp113), пятой (Ser204 и Ser207) и шестой (Phe259 и Phe290) петель $\alpha$-спирали, а их пространственная ориентация в структуре трансмембранно локализованной $\alpha$-спирали скоординирована с комплементарными сайтами молекулы эпинефрина. По этой причине обязательным требованием для высокоаффинного связывания c R-эпинефрином является 3D-конформация протеина $\beta_{2}$-адренорецептора, организованная по типу «кармана», в котором остаток Аsp ответственен за связывание с атомом азота в структуре лиганда, в то время как два остатка Ser связывают гидроксильные группы его фенольного кольца.

По этой причине все клинически значимые агонисты $\beta_{2}$-адренорецепторов содержат в своей молекуле бензольный цикл с боковой двухуглеродной цепью и концевой (замещенной) ами- ногруппой, а также нередко в положениях 3 и 4 бензольного цикла свободные гидроксильные группы, что делает их максимально похожими на катехоламины, как в случае с изопротеренолом, являющимся наиболее мощным агонистом $\beta_{1} / \beta_{2}$-адренорецепторов. В случае перепозиционирования гидроксильной группы в бензольном цикле, как, например, в молекуле сальбутамола, или замещения аминогруппы агонист приобретает меньший потенциал по сравнению с изопротеренолом, но вместе с тем приобретает резистентность к деградации под действием КОМТ и меньший аффинитет к $\beta_{1}$-адренорецепторам (Cazzola et al., 2012). Как видно из рисунка 1, структура молекулы сальбутамола соответствует всем требованиям эффективного связывания с активными сайтами $\beta_{2}$-адренорецепторов.<smiles>CNC[C@H](O)c1ccc(O)c(O)c1</smiles>

Адреналин (эпинефрин)<smiles>CC(C)(C)NCC(O)c1ccc(O)c(CO)c1</smiles>

Сальбутамол<smiles>CC(C)NCC(O)c1ccc(O)c(O)c1</smiles>

Изопротеренол

Рис. 1. Структура лигандов $\beta_{2}$-адренорецепторов адреналина, изопреналина и сальбутамола

В эксперименте in vitro аффинитет в отношении $\beta$-адренорецепторов, экспрессируемых в предсердиях и трахеях у морских свинок, выраженный в логарифмических единицах, составляет 1,86 и 2,19 соответственно. В ходе анализа тканевой селективности установлено, что R-сальбутамол почти в 24 раза интенсивнее связывается с трахеей, чем с предсердиями. По сравнению c R-изопротеренолом сальбутамол проявил несколько больший потенциал связывания с рецепторами в траxee. Soriano-Ursúa et al. (2010) с применением метода молекулярного докинга подтвердили наличие большего аффинитета $\mathrm{R}-э$ нантиомеров (эутомеров) бронхолитиков и их способности активировать $\beta_{2}$-адренорецепторы по сравнению c S-энантиомерами (дистомерами). В исследовании in vitro с применением культуры клеток, экспрессирующих $\beta_{2}$-адренорецепторы человека, R-сальбутамол продемонстрировал в 90-100 раз больший аффинитет в отношении $\beta_{1}$ - и $\beta_{2}$-адренорецепторов по сравнению с дистомером, что ассоциировалось с 23-кратным увеличением внутриклеточного уровня цАМФ, в то время как рацемический сальбутамол увеличивал концентрацию цАМФ в 24 paza (Penn et al., 1996; Page and Morley, 1999).

Внутриклеточные сигнальные каскады, ассоциированные с $\boldsymbol{\beta}_{2}$-адренорецепторами. Связывание лиганда с активными сайтами $\beta_{2}$-адренорецепторов индуцирует конформационные изменения G-белка, сцепленного с внутриклеточным доменом $\alpha$-спирали. После таких конформационных изменений G-протеин приобретает функции триггера, запускающего обмен гуаниновых нуклеотидов (guanine nucleotide exchange factor, или GEF): от $\alpha$-субъединицы G-белка отщепляется ГДФ, a вместо него присоединяется ГТФ, что приводит к полной диссоциации комплекса «рецептор - G-белок», при этом фрагменты этого комплекса, а именно $\mathrm{G}_{\alpha}-$-ГТФ и $\mathrm{G}_{\beta \gamma}$, активируют эффекторные протеины, главным из которых является фермент аденилатциклаза. Активация аденилатциклазы приводит к гидролизу АТФ и накоплению в цитоплазме клетки циклического аденозинмонофосфата (цАМФ), который, в свою очередь, индуцирует протеинкиназу А, фосфорилирующую ряд таргетных 
протеинов клетки, приводящих к снижению внутриклеточного уровня ионов кальция, подавлению гидролиза фосфоинозитида и снижению продукции инозитолтрифосфата (ИТВ), ингибированию киназы легких цепей миозина, открытию кальцийзависимых калиевых каналов, приводящих к реполяризации клетки и секвестрации ионов кальция во внутриклеточные хранилища и, в конечном итоге, релаксации гладкомышечных клеток (Cazzola et al., 2012; Theron et al., 2013).

Бронхолитическая активность. По данным Lemoine et al. (1992), сальбутамол и R-изопреналин индуцируют максимальную релаксацию гладких мышц трахеи морских свинок на фоне парциальной и максимальной контрактильности, индуцированной различными дозами карбахола, причем активность рацемического сальбутамола, как предположили исследователи, обусловлена R-энантиомером. Delmotte and Sanderson (2008) изучили эффекты сальбутамола и его энантиомеров на сократительную способность гладкомышечных клеток дыхательных путей и $\mathrm{Ca}^{2+}$-зависимую сигнализацию в срезах легких мышей с применением фазоконтрастной и конфокальной микроскопии. R-сальбутамол индуцировал дозозависимую релаксацию гладкомышечных клеток на фоне метахолин-индуцированного сокращения, в то время как S-сальбутамол не оказывал значимых эффектов. Релаксирующий эффект эутомера был сходен с таковым у рацемического сальбутамола, вводившегося в экспериментальную систему в два раза большей концентрации.

Метахолин-индуцированная контрактильность клеток коррелировала с увеличением внутриклеточных токов ионов кальция, интенсивность которых снижалась в присутствии R-энантиомера и рацемата в сходных концентрациях. В то же время эутомер проявил более выраженную активность в снижении чувствительности к $\mathrm{Ca}^{2+}$ гладкомышечных клеток. S-энантиомер не влиял на кальциевые токи и чувствительность к кальцию в обеих моделях. Исследователи заключили, что R-энантиомер сальбутамола индуцирует более выраженную релаксацию гладкомышечных клеток дыхательных путей по сравнению с рацематом, в то время как S-энантиомер может быть ответственен за редуцирование его эффектов. Приведенные данные указывают на то, что все известные $\beta_{2}$-адренорецепторзависимые эффекты рацемического сальбутамола, включая бронходилатацию, реализуются за счет его R-энантиомера. Westerhof et al. (2005) изучили бронхопротективные эффекты сальбутамола и его энантиомеров у морских свинок на фоне их ингаляционного введения в терапевтически релевантных дозах. Базальная реактивность дыхательных путей экспериментальных животных в ответ на введение гистамина редуцировалась по прошествии 30 минут после ингаляции рацемата и его R-энантиомера. Бронхопротективное действие нивелировалось через 3 ч после инициирования эксперимента. На фоне ингаляционного введения за 30 минут до и 5,5 ч после нагрузки аллергеном рацемат и его эутомер подавляли аллерген-индуцированную гиперреактивность дыхательных путей на введение гистамина, полностью устраняя раннюю астматическую реакцию и проявляя тенденцию к супрессии поздней астматической реакции. При этом интенсивность подавления поздней реакции (на пятый час эксперимента) более выражена у животных, получавших R-сальбутамол. Введение S-сальбутамола не ассоциировалось со значимыми изменениями базальной реактивности или аллерген-индуцированной бронхоконстрикции. Ни рацемат, ни отдельные энантиомеры не влияли на интенсивность инфильтрации дыхательных путей воспалительными клетками. Таким образом, ингаляционное введение рацемического сальбутамола и его R-энантиомера в эквипотентных дозах эффективно подавляет ранние и поздние астматические реакции у морских свинок, индуцированные введением аллергена, при этом эутомер проявляет немногим более выраженное бронхопротективное действие. S-сальбутамол не оказывает неблагоприятных эффектов.

В рамках рандомизированного, перекрестного исследования Arroyo et al. (2016) проводилась сравнительная оценка эф- фектов сальбутамола и левосальбутамола у лошадей с рекуррентной обструкцией дыхательных путей на фоне их ингаляционного введения с помощью небулайзера. Продолжительность действия сальбутамола составила 60 , а левосальбутамола 120 минут. При этом значения эффективной дозы $\left(\mathrm{ED}_{\max }\right)$ обоих бронхолитиков отличались незначимо и составляли в среднем 125 и 188 мкг соответственно $(\mathrm{P}=0,068)$. Бронхолитическая активность сальбутамола и левосальбутамола также значимо не различалась в группах животных: максимальное изменение транспульмонарного давления $\left(\mathrm{DP}_{\max }\right)$ составило $61,1 \%$ и $59,9 \%$ соответственно $(\mathrm{P}=0,860)$. Таким образом, у лошадей с бронхолегочной обструкцией эффективность левосальбутамола эквивалентна таковой у сальбутамола, в то время как продолжительность действия энантиомерно чистой субстанции как минимум в два раза выше по сравнению с рацематом.

Влияние на контрактильность диафрагмальных мышц. Хроническая обструкция дыхательных путей, в частности, при ХОБЛ, ассоциируется с дисфункцией респираторных мышц, обусловленной хронической гипоксией и гиперкапническим ацидозом (Esau, 1989; Xu et al., 2006; Angulo et al., 2009). Селективные агонисты $\beta_{2}$-адренорецепторов могут оказывать прямое инотропное действие, выражающееся в улучшении контрактильности диафраграмальных мышц, тем самым препятствуя прогрессированию респираторной недостаточности (Ito et al., 2006; Uzuki et al., 2006; Uzuki et al., 2007). Angulo et al. (2009) в эксперименте на крысах линии Sprague-Dawley установили, что обструкция дыхательных путей, индуцированная перевязкой трахеи, сопровождается значимым снижением артериального $\mathrm{pH}$ и увеличением парциального давления углекислого газа $\left(\mathrm{PaCO}_{2}\right)$ и уровня бикарбоната по сравнению со здоровыми животными $(\mathrm{P}<0,05)$ на фоне значимого редуцирования пикового напряжения и контрактильности диафрагмальных мышц. Указанные неблагоприятные эффекты нивелировались у крыс, получавших острое и длительное лечение сальбутамолом. В рамках исследования Píriz et al. (2008), проводившегося на крысах с индуцированным перитонеальным сепсисом, введение сальбутамола ассоциировалось со значимым увеличением аортального кровотока и повышением ЧСС на фоне сопутствующего снижения АД, повышения силы диафрагмального сокращения.

Ранее в эксперименте in vitro Van Der Heijden et al. (1997) подтвердили способность сальбутамола оказывать позитивное инотропное действие на диафрагмальные мышцы. Данный эффект устранялся блокатором рианодиновых рецепторов саркоплазматического ретикулума, что указывает на то, что контрактильные эффекты бронхолитика реализуются за счет увеличения выброса внутриклеточного кальция (Van Der Heijden et al., 1997). По данным других групп исследователей, у собак, в отличие от ряда иных агонистов $\beta_{2}$-адренорецепторов, сальбутамол ни в одной из тестировавшихся доз не оказывает значимого влияния на трансдиафрагмальное давление, генерируемое супрамаксимальной электрической стимуляцией диафрагмального нерва на фоне внутривенного болюсного или инфузионного введения лекарственного средства, что указывает на отсутствие значимой инотропной активности бронхолитика у данного вида лабораторных животных (Derom et al., 1997). Видимо, у человека сальбутамол также лишен клинически значимого инотропного потенциала (Javaheri et al., 1988).

\section{Гиперреактивность дыхательных путей - обратная сторона бронхолитического действия агонистов $\beta_{2}$-адренорецепторов}

Имеются свидетельства того, что регулярное ингаляционное введение рацемического сальбутамола в кумулятивных дозах ассоциируется с парадоксальными реакциями у некоторых пациентов с бронхообструктивными заболеваниями (Page and Morley, 1999), выражающимися в парциальном снижении бронхопротективного эффекта и увеличении гиперреактивности дыхательных путей в ответ на действие провокативных 
факторов (Cockcroft et al., 1999; Nelson, 1999). Подобный феномен вряд ли ассоциирован с активацией $\beta_{2}$-адренергических рецепторов, в силу чего возникло предположение о возможной роли S-энантиомера в развитии данной реакции (Page and Morley, 1999). Handley et al. (1998) указывают на то, что развитие гиперреактивности дыхательных путей исключено в случае регулярного ингаляционного введения левосальбутамола.

В этой связи обращает на себя внимание исследование Matera et al. (2011), где в эксперименте in vitro с применением бронхов, изолированных у здоровых лошадей и животных с рекуррентной обструкцией дыхательных путей, установлено, что ни один из энантиомеров сальбутамола не оказывает релаксирующего действия на фоне субмаксимального плато контрактильности, индуцированной карбахолом, но при этом по сравнению с контролем и R- и S-сальбутамол оказывали слабое, но значимое контрактильное действие $(\mathrm{P}<0,05)$. В то же время эутомер индуцировал значимую релаксацию мышц на фоне гистамин-индуцированного сокращения (бронхи здоровых лошадей - 92,1 $\pm 2,0 \%$, бронхи лошадей с обструкцией $100,2 \pm 4,0 \%, \mathrm{P}<0,01)$, а дистомер оказывал лишь слабое релаксирующее действие (бронхи здоровых лошадей - 15,8 \pm $5,7 \%$, бронхи лошадей с обструкцией $-12,4 \pm 5,2 \%$ ) по сравнению с папаверином. Инкубирование с R- или S-сальбутамолом ассоциировалось со смещением кривой контрактильности мышц здоровых животных в ответ на карбахол вправо относительно контроля $(\mathrm{P}<0,001)$ и с отсутствием значимых изменений в эксперименте с применением бронхов лошадей с обструкцией.

B нормальных бронхах R-сальбутамол приводил к значимому снижению $\mathrm{E}_{\max }(6,36 \pm 0,21$ против 9,07 \pm 0,68 г в контроле, $\mathrm{P}<$ $0,01)$ и редуцировал активность потенциала в отношении мышц животных с обструкцией $\left(\mathrm{EC}_{50} 7,10 \pm 0,35\right.$ мкмоль, $\mathrm{P}<$ 0,001). В случае применения S-сальбутамола кривая концентрации гистамина смещалась влево для бронхов здоровых животных $(2,25 \pm 0,19$ мкмоль против контроля 7,00 $\pm 0,29$ мкмоль, $\mathrm{P}<0,001)$ и лошадей с обструкцией $(1,50 \pm 0,80$ мкмоль против контроля $2,80 \pm 0,26$ мкмоль, $\mathrm{P}<0,05)$. Таким образом, S-сальбутамол у лошадей умеренно потенцирует контрактильность гладкомышечных стенок дыхательных путей, индуцированную карбахолом, а также вызывает гиперреактивность на фоне введения гистамина. Эти данные подтверждают способность S-энантиомера сальбутамола потенцировать контрактильные ответы спазмогенов.

Примером того, что S-энантиомеру сальбутамола присущ ряд фармакологических свойств, не связанных с его $\beta_{2}$-адренергическим потенциалом, может служить работа Keir et al. (2002). Они в эксперименте на овальбумин-сенсибилизированных морских свинках, получавших в течение 10-дневного периода посредством длительной подкожной инфузии (RS)-, Rили S-сальбутамола (1 мг/кг·день) установили, что регулярное введение рацемата или S-энантиомера ассоциируется со значимым увеличением реактивности дыхательных путей на различные провокационные стимулы, при этом сопутствующее введение капсаицина предупреждает этот эффект. Интересно, что броходилатирующая активность рацемата после его острого внутривенного введения животным, получавшим R,S-, R- или S-сальбутамол, не снижалась по сравнению с животными, получавшими плацебо. В итоге, Keir et al. (2002) пришли к выводу, что толерантность к бронхолитическим эффектам R,S-, $\mathrm{R}$ - или S-сальбутамола, развивающаяся при длительном введении, скорее всего, не связана с оккупацией $\beta_{2}$-адренорецепторов или их десенситизацией, а, как минимум частично, со снижением восприимчивости капсаицин-чувствительных нервов.

По данным другого эксперимента с аналогичным дизайном также сделаны подобные выводы. У морских свинок подкожное введение рацемического сальбутамола в дозе 0,2 мг/кг·день в течение 10 суток также ассоциировалось с частичным увеличением бронхореактивности на введение гистамина, метахолина и бомбезина. Последующее острое внутривенное введение сальбутамола подавляло бомбезин-индуцированную бронхо- констрикцию. С учетом того, что сальбутамол сохраняет свои бронходилатирующие эффекты, десенситизация $\beta_{2}$-адренорецепторов, возможно, не является основной причиной развития толерантности к бронхолитику при его регулярном применении (Buchheit et al., 1995). S-сальбутамол метаболизируется значительно медленнее по сравнению с эутомером и сохраняется преференциально в верхних дыхательных путях, что может стать триггером парадоксальных эффектов при регулярном применении рацемата в высоких дозах (Page and Morley, 1999). Это указывает на то, что дистомеры агонистов $\beta_{2}$-адреномиметиков могут являться причиной повышения заболеваемости и смертности у пациентов с бронхиальной астмой (Handley et al., 1998; Ameredes and Calhoun, 2010). В эксперименте Mazzoni et al. (1994) острое подкожное инфузионное введение рацемического сальбутамола $(0,69$ мкг/кг'мин в течение менее 1 ч) ассоциировалось с полным подавлением аллергического бронхоспазма у сенситизированных морских свинок. Более длительное введение приводило к прогрессивному повышению чувствительности животных к антигену в условиях его ингаляционного введения, при этом через 48 ч после ингаляции в группах экспериментальных животных регистрировались случаи развития коллапса и смерти. Между тем, острая инфузия рацемата в дозе 1,67 мкг/кг'мин подавляла обструкцию дыхательных путей, что, вероятно, обусловлено активацией $\beta_{2}$-адренорецепторов R-сальбутамолом, в то время как внутривенное введение S-энантиомера в аналогичной дозе индуцировало гиперреактивность к гистамину без сопутствующего изменения калибра дыхательных путей. Результаты этих наблюдений указывают на то, что при подкожном инфузионном введении рацемический сальбутамол первоначально предотвращает бронхоконстрикторные ответы на антиген в силу доминирования бронходилатирующей активности эутомера над способностью дистомера индуцировать гиперреактивность. Конверсия протективного действия на повышение чувствительности к антигену не связана с редуцированием пула $\beta_{2}$-адренорецепторов или интенсивности их стимуляции, поскольку в эксперименте подкожное введение рацемата или ингаляция рацемического изопреналина оказывали протективные эффекты против летальных доз антигена. Прогрессивное снижение эффективности $\mathrm{R}$-сальбутамола может являться следствием диспропорциональной кумуляции дистомера у животных подобно человеку в силу стереоселективности метаболизма R-сальбутамола.

Для того, чтобы внести ясность в возможные механизмы парадоксального бронхоконстрикторного действия дистомера сальбутамола, обратим внимание на работу Mitra et al. (1998), которые изучили эффекты S-сальбутамола на внутриклеточный уровень кальция $\mathrm{Ca}^{2+}$ в культуре диссоциированных гладкомышечных клеток бычьей трахеи. Так, S-сальбутамол в концентрациях выше 1 пмоль и рацемат в концентрации 1 нмоль индуцировали увеличение $\mathrm{Ca}^{2+}$ на 150 и 100 нмоль соответственно, что строго контрастировало с R-энантимером, индуцировавшим снижение концентрации ионов. Увеличение $\mathrm{Ca}^{2+}$ блокировалось в присутствии атропина и 4-дифенилацетокси$\mathrm{N}$-метилпиперидина, но интенсифицировалось на фоне ICI118551 - блокатора $\beta_{2}$-адренорецепторов. При 30-секундной экспозиции дистомером в клетках регистрировали увеличение уровня инозитолтрифосфата в среднем на $213,0 \pm 34,4 \%$. Отсутствие значимых изменений $\mathrm{Ca}^{2+}$ в среде, свободной от ионов кальция, указывает на то, что эффекты S-сальбутамола обусловлены увеличением внутриклеточных токов ионов. Исследователи заключили, что S-сальбутамол может перекрестно реагировать с мускариновыми рецепторами. При этом, Bosak et al. (2017) в эксперименте с применением трех вариантов бутирилхолинэстеразы (BChE), выделенной из плазмы донорской крови, а также рекомбинантной $\mathrm{AChE}$ человека, установили, что $\beta_{2}$-адреномиметики, в том числе сальбутамол, обладают свойствами обратимых ингибиторов холиэстеразы. При этом ингибиторная активность сальбутамола в отношении $\mathrm{AChE}\left(\mathrm{K}_{\mathrm{i}}\right.$ $2,0 \pm 0,2$ ммоль) почти в два раза превышает таковую у тербу- 
талина (4,8 $\pm 0,2$ ммоль). В отношении типичной ВChE активность сальбутамола увеличивается в 28 раз $(0,071 \pm 0,006$ ммоль). Связывание с активными центрами холинэстераз не является стереоселективным. Так, значения $\mathrm{K}_{\mathrm{i}} \mathrm{R}$-сальбутамола для $\mathrm{AChE}$ и $\mathrm{BChE} \mathrm{составили} 4,0 \pm 0,3$ и 0,19 $\pm 0,04$ ммоль, S-сальбутамола $-1,8 \pm 0,1$ и $0,31 \pm 0,05$ ммоль, соответственно. С учетом приведенных данных можно предположить, что в условиях экспозиции оба энантиомера могут индуцировать локальное повышение активности холинергической системы, в том числе за счет подавления активности $\mathrm{AChE}$ в синаптической щели холинергических синапсов, увеличивая тем самым уровень медиатора ацетилхолина и косвенно интенсифицируя его бронхоконстрикторное действие.

Agrawal et al. (2004) сравнили клеточные эффекты сальбутамола и его энантиомеров на внутриклеточную сигнализацию, вовлекаемую в констрикторные и воспалительные ответы гладкомышечных клеток бронхов человека. В первичной культуре миоцитов S-энантиомер значимо и дозозависимо индуцировал увеличение экспрессии и активности $\mathrm{G}_{\mathrm{i} \alpha}$-протеина и снижение экспрессии $\mathrm{G}_{\mathrm{s}}$-протеина адренорецепторов. Рецептор-независимая активация аденилатциклазы форсколином устранялась в присутствии S-сальбутамола. По прошествии 24 ч инкубирования с дистомером в клетках отмечали увеличение $\mathrm{Ca}^{2+}$ в ответ на стимуляцию метахолином. Эффекты Sсальбутамола полностью противоположны таковым у R-энантиомера, а активность рацемического сальбутамола по некоторым параметрам сходна с таковой у дистомера. S-сальбутамол индуцировал активацию PI3-киназы и NF-кB в гладкомышечных клетках. Таким образом, экспериментально установлено, что S-сальбутамол может вызывать ир-регуляцию экспрессии и активности проконстрикторных путей с участием $\mathrm{G}_{\mathrm{i} \alpha}$ протеина, $\mathrm{Ca}^{2+}$, а также снижать активность бронходилатирующих механизмов с участием $\mathrm{G}_{\mathrm{s}}$-протеина. Дистомер также индуцирует провоспалительные каскады с участием PI3киназы и NF-кB. C учетом того, что S-сальбутамол метаболизируется в 10 раз медленней по сравнению с эутомером, и его $\mathrm{T}_{1 / 2}$ более продолжителен, очевидно, что гладкомышечные клетки могут подвергаться длительной экспозиции S-сальбутамолом, что увеличивает риск его неблагоприятных провоспалительных и констрикторных эффектов в случае систематического приема рацемического сальбутамола при хронических заболеваниях, в том числе при бронхиальной астме. По данным других исследователей, устранение из рацемата S-сальбутамола, обладающего провоспалительными свойствами, может элиминировать персистирующую обструкцию бронхов и снижать их эластичность, ассоциированную с увеличением интенсивности воспаления, уменьшением отека и подавлением активации лейкоцитов при ХОБЛ (Costello, 1999).

Некоторые исследователи все же не исключают, что развитие гиперреактивности дыхательных путей и снижение бронхопротекторного действия сальбутамола на молекулярном уровне может объясняться функциональной десентиситизацией (down-регуляция) $\beta_{2}$-адренорецепторов, экспрессируемых в гладкомышечных клетках дыхательных путей с сопутствующим повышением активности ассоциированной с ними аденилатциклазы (Herepath and Broadley, 1992; Hauck et al., 1997; Boskabady and Aslani, 2007). Cooper and Panettieri (2008) в эксперименте с применением тонких срезов легкого человека, содержащих фрагменты дыхательных путей, установили, что сальбутамол стимулирует время- и дозозависимое снижение изопротеренол-индуцированой релаксации, достигающей $45,0 \%$ $(\mathrm{P}=0,011)$. Это указывает на способность бронхолитика в условиях длительной экспозиции десенситизировать $\beta_{2}$-адренорецепторы за счет активации протеинкиназы А. Указанный эффект сальбутамола нивелировался в присутствии дексаметазона. Позднее подтверждена роль глюкокортикостероидов в превентировании и реверсировании толерантности $\beta_{2}$-адренорецепторов на фоне десенситизирующих эффектов длительнодействующих $\beta_{2}$-адреномиметиков (Cooper et al., 2011). Это указывает на то, что десенситизация рецепторов дыхательных путей является класс-специфическим эффектом агонистов $\beta_{2}$-адренорецепторов. После связывания с агонистом $\beta_{2}$-адренорецепторы подвергаются быстрой интернализации с последующим перераспределением (эндоцитозом) рецепторов из плазматической мембраны в цитозольные везикулы.

\section{Дополнительные благоприятные эффекты $\beta_{2}$-агонистов}

Влияние на мукоцилиарный клиренс. Важным эффектом агонистов $\beta_{2}$-адренорецепторов является увеличение частоты биения ресничек мерцательного эпителия, интегрального показателя мукоцилиарного клиренса. По данным Sabater et al. (2005), у овец сальбутамол (180 мкг) и сальмотерол (42 мкг) значимо интенсифицируют обмен трахеальной слизи (tracheal mucus velocity (TMV) в течение 6-часов после ингаляционного введения, а также нивелируют неблагоприятные эффекты ингаляционного введения эластазы нейтрофилов человека, выражающиеся в снижении мукоцилиарного клиренса. В эксперименте с применением овечьих эпителиоцитов дыхательных путей и метода цифровой видеомикроскопии Frohock et al. (2002) подтвердили способность R-энантиомера рацемического сальбутамола дозозависимо стимулировать повышение активности ресничек мерцательного эпителия на $24,4 \pm 5,4 \%$ в сравнении с базальным уровнем $(7,2 \pm 0,2 \%)$, в то время как рацемат - всего на $12,8 \pm$ $3,6 \%$, что значимо меньше в сравнении с энантиомером, несмотря на его присутствие в рацемате в эквипотентной концентрации.

По данным регистрации внутриклеточных токов кальция в отдельных клетках установлено, что стимулирующий эффект $\mathrm{R}$-сальбутамола ассоциирован со стимуляцией $\beta_{2}$-адренорецепторов и активацией протеинкиназы $\mathrm{A}$ по $\mathrm{Ca}^{2+}$-зависимому и $\mathrm{Ca}^{2+}$-независимому механизмам. Дистомер индуцировал лишь ничтожно малые изменения активности ресничек эпителиоцитов и не изменял концентрацию внутриклеточного кальция. Таким образом, позитивные эффекты рацемического сальбутамола на цилиарный клиренс обусловлены присутствием в его составе R-энантиомера.

McAuley et al. (2004) в рамках проспективного, рандомизированного исследования на лабораторных крысах с нормальной легочной функцией и с экспериментально индуцированным повреждением легких установили, что рацемический сальбутамол $\left(10^{-5}\right.$ моль) и изопротеренол $\left(10^{-6}\right.$ моль) стимулируют повышение клиренса альвеолярной жидкости до уровня, сравнимого с максимальным при введении дибутирил-цАМФ (32,9 $\pm 10,9 \% / ч$ против базального 7,6 $\pm 2,2 \% /$ ч, $\mathrm{P}<0,05)$. По сравнению с базальным уровнем и рацемический сальбутамол $\left(10^{-6}\right.$ моль) и его эутомер $\left(10^{-6}\right)$ вызывают сходное увеличение клиренса альвеолярной жидкости $(14,5 \pm 3,0 \%(\mathrm{P}<0,05)$ и $15,0 \pm$ $4,6 \%(\mathrm{P}<0,05)$ без значимых различий между группами. Таким образом, в клинически релевантных концентрациях сальбутамол и его эутомер стимулируют в здоровых легких цАМФ-зависимое повышение альвеолярного клиренса и редуцируют легочный отек в условиях легочного повреждения за счет увеличения альвеолярного клиренса и снижения эндотелиальной проницаемости. Данные исследований in vitro указывают на то, что S-энантиомер сальбутамола может индуцировать мукоцилиарную дисфункцию.

Противовоспалительная активность. В настоящее время имеются доказательства наличия у агонистов $\beta_{2}$-адренорецепторов не только бронходилатирующей активности, но и широкого спектра противовоспалительных эффектов, потенциально увеличивающих их клиническое значение в лечении пациентов с бронхообструктивными заболеваниями, имеющими воспалительный компонент. Reinero et al. (2009) в рандомизированном перекрестном эксперименте на здоровых кошках и животных с экспериментально индуцированной бронхиальной астмой, получавших длительно ингаляционно рацемический сальбутамол или один из его энантиомеров, установили, что в обеих группах рацемат и S-сальбутамол статистически значи- 
мо увеличивают клеточность бронхоальвеолярного лаважа $(\mathrm{P}=0,04$ и $\mathrm{P}=0,02)$ по сравнению с животными, получавшими $\mathrm{R}$-сальбутамол или плацебо. При этом число эозинофилов в лаваже и активность TNF- $\alpha$ были значимо выше у кошек с бронхиальной астмой, чем у животных, получавших другие исследуемые виды терапии $(\mathrm{P}=0,03$ и $\mathrm{P}=0,004)$. У здоровых животных число нейтрофилов в лаваже повышалось на фоне введения рацемата и $\mathrm{S}-$ сальбутамола $(\mathrm{P}=0,04)$. Таким образом, регулярное ингаляционное введение рацемического сальбутамола или его дистомера, в отличие от R-сальбутамола, у здоровых кошек и животных с бронхиальной астмой ассоциируется с развитием воспалительного процесса.

В экспериментах на мышах с острым IgG- или ЛПС-индуцированным повреждением легких $\mathrm{S}$-сальбутамол значимо ( $\mathrm{P}<0,01$ и $\mathrm{P}<0,05$, соответственно) снижал выход альбумина в бронхоальвеолярную жидкость, в то время как R-энантиомер в эквипотентной концентрации оказывал лишь статистически незначимое влияние. Эффект S-сальбутамола сочетался с почти $70 \%$ снижением уровня полимофоядерных клеток в бронхоальвеолярной жидкости ( $\mathrm{P}<0,001$ и $\mathrm{P}<0,01)$, а также ряда цитокинов, включая CXCL1, MCP-1 (CCL2), TNF- $\alpha$ (P < 0,05), играющих ключевую роль в патогенезе острого легочного IgGиндуцированного повреждения. В эксперименте in vitro в ЛПСстимулированных макрофагах перитонеального экссудата, выделенного у мышей, S-сальбутамол значимо редуцировал уровни интерлейкина 6 (IL-6), IL-12, KC, MCP-1, MIP-1 $\alpha$, TNF$\alpha$ и IFN- $\gamma$ на фоне сопутствующего $31 \%$ снижения уровня фосфорилированной JNK. В дополнительном эксперименте установлено, что снижение продукции TNF- $\alpha$ может быть связано как раз с подавлением активации JNK в макрофагах. Подтверждена способность S-сальбутамола почти в два раза стимулировать выброс IL-10 ЛПС-стимулированными макрофагами, известного своей способностью ингибировать экспрессию цитокинов в активированных макрофагах. По данным гистопатологического исследования, у мышей, получавших S-сальбутамол, в некоторых альвеолярных пространствах отмечалось значимо меньшее отложение фибрина и числа эритроцитов (Bosmann et al., 2012).

Также известно, что цАМФ-зависимая сигнальная трансдукция, в том числе ассоциированная с активацией $\beta_{2}$-адренорецепторов, оказывает негативное модулирующее действие на дегрануляцию эозинофилов человека, активируемую $\mathrm{IgG}$ или секреторным IgA. Подавление активации эозинофилов $\beta_{2}$-агонистами может иметь большое клиническое значение за счет подавления выброса эозинофильных цитотоксических протеинов, промотирующих развитие аллергии и воспаления in vivo (Momose et al., 1998). В связи с этим отметим экспериментальную работу Ferrada et al. (2008), в которой установлено, что у мышей с аллергическим воспалением легких, индуцированным сенсибилизацией животных овальбумином, получавших посредством подкожной инфузии R-сальбутамол (200 мкг/100 мкл), отмечалось выраженное, хотя и не значимое по сравнению с контролем, снижение уровней эозинофилов в бронхоальвеолярном лаваже и сывороточного $\operatorname{IgE}$. В активированных спленоцитах мышей только энантиомер индуцировал значимое снижение экспрессии мPHК IL-2 и IL-13, без значимых различий в группах по уровню IL-6. В митоген-активированных T-клетках в присутствии R-энантиомера снижались уровни мPHK IL-2, IL-13 (значимо), IL-6 (незначимо) и активность NF-кB (незначимо). В другом исследовании у мышей с экспериментально индуцированной бронхиальной астмой R-сальбутамол значимо редуцировал выход эозинофилов в бронхоальвеолярную жидкость и ткани дыхательных путей, подавлял гиперплазию гоблетовских клеток и слизистую окклюзию, а также снижал уровни IL-4 в бронхоальвеолярном лаваже и овальбумин-специфического IgE в плазме крови. Несмотря на наличие некоторых из этих позитивных эффектов, S-сальбутамол интенсифицировал отек и реактивность дыхательных путей у животных в ответ на введение метахолина, в то время как эутомер не оказывал влияния на легочную механику и развитие отека. Вероятно, оба энантиомера сальбутамола редуцируют траффик эозинофилов в верхних дыхательных путях и гиперсекрецию слизи у мышей с бронхиальной астмой, но $\mathrm{S}$-сальбутамол потенцирует развитие отека и гиперреактивность, что может лимитировать клиническую эффективность рацемического сальбутамола (Henderson et al., 2005). Volcheck et al. (2005), в свою очередь, подтвердили наличие у R-сальбутамола противовоспалительной активности. Так, in vitro рацемический сальбутамол ингибировал IL-5-активированную продукцию супероксидных радикалов эозинофилами человека. Указанный эффект усиливался в присутствии IBMX - ингибитора фосфодиэстеразы и реверсировался на фоне ICI 118, 551 селективного антагониста $\beta_{2}$-адренорецепторов. При обработке клеток только R-энантиомером отмечался аналогичный эффект, достигавший максимума через 60 минут, но исчезавший при более длительном инкубировании. Интересно, что S-сальбутамол в присутствии IBMX не влиял на секрецию супероксида IL-5-активированными клетками в первые 60 мин инкубирования, но значимо ее усиливал в последующий период. S-сальбутамол не оказывал модифицирующего влияния на ингибиторную активность R-энантиомера в составе рацемата. Таким образом, при изолированном применении энантиомеры оказывают разнонаправленные эффекты на выброс провоспалительных медиаторов из активированных эозинофилов человека. Кинетика этих эффектов различна и в случае одновременного введения в составе рацемата, вероятно, активность $\mathrm{R}$-сальбутамола имеет преференциальное значение.

Чуть ранеe Baramki et al. (2002) высказали предположение о том, что противовоспалительные эффекты R-энантиомера, реализуемые посредством активации $\beta_{2}$-адренорецепторов T-лимфоцитов, могут маскироваться в присутствии S-сальбутамола, в случае введения рацемата in vivo. В эксперименте с применением антиген-специфических Т-клеточных линий, обработанных рекомбинантным IL-2 человека и столбнячным токсином, R-сальбутамол значимо ингибировал пролиферацию Т-клеток: в концентрации $10^{-8}$ моль/л - на 77,0 $\pm 9,7 \%$ и в концентрации $10^{-7}$ моль/л - на $61,1 \pm 9,0 \%$ по сравнению с контролем. S-сальбутамол при его изолированном применении не оказывал влияния, но в сочетании с эутомером индуцировал дозозависимое увеличение пролиферации клеток. В эквивалентных концентрациях обоих изомеров пролиферация не изменялась по сравнению с контролем, но в конщентрации $10^{-6}$ моль/л $\mathrm{S}$-сальбутамол увеличивал пролиферацию. Антипролиферативное действие эутомера и стимулирующие эффекты комбинации энантиомеров блокировались в присутствии пропранолола. R-сальбутамол в концентрации $10^{-8}$ подавлял продукцию IL-2 и IFN- $\gamma$, но комбинация энантиомеров (10 8 эннантиомер) не оказывала влияния на секрецию цитокинов. При сочетанном применении R-энантиомера в концентрации $10^{-8}$ моль/л с $\mathrm{S}$-сальбутамолом в концентрации $10^{-6}$ моль/л увеличивалась продукция IL-2 и IL-13. Приведенные данные подтверждают наличие противовоспалительных эффектов R-энантиомера, обусловленных активацией $\beta_{2}$-адренорецепторов, в то время как рацемат проявляет лишь минимальное влияние на пролиферацию или продукцию цитокинов Т-клетками. Избыточное присутствие S-сальбутамола ассоциируется с его провоспалительными эффектами. Возможно, последний проявляет свойства обратного агониста, переключающего функции $\beta_{2}$-адренорецепторов.

При этом Chorley et al. (2006) предположили, что острая стимуляция эпителиальных клеток дыхательных путей сальбутамолом может подавлять продукцию и высвобождение провоспалительных медиаторов, в том числе GM-CSF посредством активации iNOS-зависимых каскадов. Исследователи провели эксперимент, в котором первичные культуры клеток бронхиального эпителия подверглись экспозиции коктейлем из цитокинов, включавшем IFN- $\gamma$ и IL- $2 \beta$, с целью индуцирования экспрессии iNOS, после чего в экспериментальную 
систему добавлялись R- и S-сальбутамол в качестве рацемической смеси. Экспрессия iNOS значимо и концентрацие-зависимо усиливалась в присутствии R-энантиомера с сопутствующим подавлением цитокин-индуцированной экспрессии мРНК и протеина GM-CSF, в то время как дистомер не оказывал влияния. В то же время для интенсификации эффектов iNOS требуется протеинкиназа С (ПКС), индуцирующая транскрипцию iNOS, в частности, еe PKC $\delta$-изоформа. R-сальбутамол активировал экспрессию РКС $\delta$ лишь частично и первоначально с последующим снижением уровня энзима по прошествии 6 ч инкубирования, что указывает на активацию $\mathrm{iNOS}$ по PKC $\delta$ независимому пути.

Auais et al. (2005) установили, что инфекция дыхательных путей, вызванная респираторным синцитиальным вирусом, у крыс сопровождается развитием нейрогенного воспаления в нижнем сегменте респираторного тракта. В другом эксперименте на инфицированных крысах исследователи установили, что экстравазация альбумина, вызванная стимуляцией сенсорных нервов капсаицином, подавляется на фоне ингаляционного введения рацемического сальбутамола в дозе 0,63 мг, в то время как в более высоких дозах бронхолитик проявляет лишь минимальный аддитивный эффект. Противовоспалительный эффект R-энантиомера значимо более выражен даже в случае его введения в меньшей дозе $(0,31$ мг), а в случае введения в высоких дозах нейрогенная экссудация полностью подавляется. S-сальбутамол не оказывает значимого противовоспалительного действия даже в дозе 1,25 мг, а с повышением дозы проявляет лишь минимальный ингибиторный эффект. Противовоспалительное действие R-сальбутамола реализуется независимо от экспрессии рецепторов substance P neurokinin 1, что указывает на его прямое действие на сосудистую стенку.

Ibe et al. (2008) в эксперименте in vitro с применением гладкомышечных клеток человека установили, что, подобно фактору роста тромбоцитов (PDGF) и фактору активации тромбоцитов (PAF), S-сальбутамол стимулирует клеточную пролиферацию, в то время как R-сальбутамол - наоборот. Поскольку PDGF и S-сальбутамол не оказывали аддитивного влияния на эффекты друг друга, вероятно, их пролиферативная активность реализуется посредством разных механизмов. По сравнению с $\mathrm{R}$-энантиомером S-сальбутамол более выраженно индуцировал экспрессию NF-кB, IкB $\alpha$, циклин-зависимых киназ 2 и 4, $\mathrm{IL}-6$, протеина ретинобластомы $(\mathrm{pRb})$ и протеина рецепторов PAF. B присутствии дистомера отмечалось увеличение секреции IL-6, а также устранение ингибиторного влияния эутомера на секрецию цитокина. Приведенные данные подтверждают способность S-сальбутамола стимулировать пролиферацию гладкомышечных клеток посредством интенсификации экспрессии и фосфорилирования внутриклеточных митогенных протеинов и стимуляции секреции IL-6. Индуцирование экспрессии белка PAF-рецепторов доказывает, что S-сальбутамол может оказывать неблагоприятные эффекты посредством связывания с G-протеин-ассоциированными рецепторами, такими, как PAF-рецептор. Позднее упомянутой группой исследователей установлено, что S-сальбутамол может время-зависимо увеличивать связывание PAF с рецептором, коррелирующее с выбросом инозитолтрифосфата, в то время как левосальбутамол и рацемат не оказывают значимых эффектов. Более того, S-сальбутамол интенсифицирует синтез PAF и подавляет его катаболизм (Bae et al., 2012). РAF является важнейшим провоспалительным липидным медиатором, активно вовлекающимся в процессы развития аллергии и воспаления в легких (Roth et al., 1996; Honda et al., 2002). Левосальбутамол в малых концентрациях ингибирует пролиферацию гладкомышечных клеток дыхательных путей человека с сопутствующей активацией цАМФ/ПКА-зависимых внутриклеточных сигнальных каскадов. В присутствии дистомера ингибиторный эффект R-энантиомера устраняется c 65\%-снижением продукции цАМФ. Левосальбутамол подавляет экспрессию NF-кB и pRb. Этот эффект устраняется в присутствии ICI-118551 - селективного блокатора $\beta_{2}$-адренорецепторов, в то время как селективный антагонист РАF-рецепторов CV-3988 подавляет пролиферативные эффекты S-сальбутамола и не влияет на активность левосальбутамола, что указывает на различие молекулярных мишеней и разные фармакологические эффекты энантиомеров (Ibe et al., 2006).

Как неоднократно показано в экспериментах, $\beta_{2}$-адреномиметики, в том числе сальбутамол, могут модулировать функции эпителиоцитов и гладкомышечных клеток дыхательных путей, включая продукцию цитокинов и TGF- $\beta$. Последний ассоциируется ремоделированием, uр-регуляцией синтеза фактора роста сосудистого эндотелия (VEGF) и стимуляцией дифференциации фибробластов в миофибробласты. Frieri and Capetandes (2008) предположили, что S-сальбутамол может индуцировать в микрофибробластах экспрессию VEGF и фибронектина в присутствии экстракта Dermatophagoides pteronyssinus. В эксперименте культуру нормальных легочных фибробластов человека стимулировали IL- $1 \beta$, TGF- $\beta$ и экстрактом $D$. pteronyssinus и далее инкубировали с энантиомерами сальбутамола. В присутствии R-сальбутамола ( $10^{-7}$ моль) секреция VEGF фибробластами возрастала почти в два раза по сравнению с S-сальбутамолом $(\mathrm{P}<0,05)$. Секреция VEGF миофибробластами также возрастала в два раза, но без значимых различий между энантиомерами. S-сальбутамол в концентрациях $10^{-8}-10^{-4}$ моль дозозависимо индуцировал повышение уровня мPHK VEGF с параллельным увеличением его секреции. По сравнению с R-энантиомером S-сальбутамол в концентрации $10^{-5}$ моль индуцировал продукцию фибронектина в миофибробластах, но не в фибробластах, активированную рекомбинантным IL-1 $1 \beta$ человека и D. pteronyssinus, а в концентрации $10^{-6}$ - увеличение основного фактора роста фибробластов (bFGF). Таким образом, в концентрации $10^{-6}$ моль S-сальбутамол, но не R-сальбутамол, может промотировать ангиогенез, увеличивать продукцию фибронектина или bFGF, что, в свою очередь, запускает процесс отложения матрикса и ремоделирования, в частности - при бронхиальной астме.

Противоаллергическое действие. Толерантность клеток-мишеней к $\beta_{2}$-адренорецептор-зависимым эффектам бронхолитиков обусловлена фосфорилированием $\beta_{2}$-адренорецепторов, катализируемым цАМФ-зависимой ПКА, а также фосфорилированием под действием киназы G-протеин-ассоциированных рецепторов (GRK), которое, в свою очередь, ведет к присоединению белка $\beta$-аррестина и интернализации рецептора (Tran et al., 2004).

Тучные клетки, локализуемые в легких и периферической крови человека, экспрессируют $\mathrm{Ca}^{2+}$-активируемые калиевые каналы (iKCa1), которые активируются по IgE-зависимому пути с развитием гиперполяризации клетки, потенцируемой внутриклеточными токами ионов кальция. Активация $\beta_{2}$-адренорецепторов, в частности, сальбутамолом ( $1^{-10}$ мкмоль), ассоциируется с подавлением токов iKCa1, индуцируемых анти- $\mathrm{IgE}$ и блокаторов рецепторов ICI 118551. Экспериментально установлено, что активность каналов iKCal регулируется $G_{\alpha s}$-протеин-ассоциированными $\beta_{2}$-адренорецепторами, активация которых в присутствии специфических агонистов оказывает мембраностабилизирующее действие на тучные клетки (Duffy et al., 2005; Wang and Lau, 2006). Chong et al. (2003) установили, что длительная экспозиция тучных клеток сальбутамолом ассоциируется с десенситизацией $\beta_{2}$-адренорецептор-зависимых ответов тучных клеток легких человека, в конечном итоге, приводящих к выбросу гистамина. Причем указанный эффект сальбутамола более выражен по сравнению с таковым у тербуталина, несмотря на эквивалентное редуцирование плотности мембранных $\beta_{2}$-адренорецепторов, достигающее примерно $25 \%$ ( $>$ > 0,05). Десенситизирующая активность в отношении тучных клеток присуща и длительно действующим агонистам $\beta_{2}$-адренорецепторов (Scola et al., 2004).

\section{Фармакокинетика}

Абсорбция и биодоступность. У кроликов после перорального и ректального введения биодоступность сальбута- 
мола не превышает 9\% и 17\%, соответственно, что указывает на наличие более высокой биодоступности сальбутамола при ректальном введении и ее снижение в случае введения вещества per os, возможно, связанным с эффектом первого пассажа (Kurosawa et al., 1993). Сальбутамол подвергается полной локальной абсорбции в двенадцатиперстной кишке, после чего частично метаболизируется в эпителиоцитах слизистой (около $20 \%$ ), а в последующем - в печени (около 80\%). В то же время при ректальном введении у кроликов сальбутамол абсорбируется слабо, подвергается минимальному метаболизму в слизистой (4\%), а его концентрация в ректальном венозном кровотоке достигает примерно 40\% с последующим прохождением вещества через печень (Kurosawa et al., 1993).

У собак в условиях ингаляционного введения R-сальбутамола с помощью небулайзера регистрируется два четко выраженных пика концентрации энантиомера в плазме крови $\left(\mathrm{C}_{\mathrm{max}}\right)$, при этом около 67\% R-сальбутамола от ингаляционной дозы поступает из кишечника. Таким образом, у собак абсорбция R-энантиомера носит двухфазный характер, обусловленный первичным всасыванием энантиомера из кишечника и позднее - из легких (Auclair et al., 2000).

Распределение и связывание с протеинами плазмы крови. Это связывание с протеинами плазмы крови и тканевое распределение хиральных субстанций носит стереоселективный характер, что, в конечном итоге, может оказывать существенное влияние не только на их общий фармакокинетический профиль, но и на характер фармакологических эффектов (Shen et al., 2013). Еще до недавнего времени отсутствовали данные об энантиоселективности фармакокинетики изомеров сальбутамола в легочной ткани. Jacobson et al. (2017) провели исследование, в рамках которого с применением техники тандемной сверхэффективной жидкостной хроматографии с масс-спектрометрией оценили концентрации энантиомеров сальбутамола по прошествии 2, 5, 10 и 15 минут, в центральных (эндоскопия бронхов) и периферических сегментах легких (чрескожная легочная биопсия) у лошадей $(\mathrm{n}=12)$ через 20 и 25 мин после ингаляционного введения рацемата в дозе 1000 мкг соответственно, а также в образцах плазмы крови. Концентрация сальбутамола в бронхоальвеолярной жидкости составила в среднем $57 \pm 10$ мг (ДИ 95\%), в то время как начальные средние уровни R- и S-сальбутамола - $389 \pm 189$ и $378 \pm 177$ нг/г соответственно, которые снижались почти на 50\% по прошествии 15 мин после ингаляции. Средние значения концентраций R- и $\mathrm{S}$-сальбутамола в центральном сегменте легких были значимо выше в сравнении с таковыми периферической части и составили соответственно $875 \pm 945$ против $49 \pm 12$ нг/г и $877 \pm 955$ против $51 \pm 12$ нг/г. Энантиоспецифичность фармакокинетического профиля сальбутамола характерна при его распределении в бронхоальвеолярном лаваже и в тканях центральной части легких, а минимальная ( 2\%) энантиоселективность характерна для периферических сегментов легких. Наличие энантиоселективности фармакокинетики сальбутамола подтверждено при распределении сальбутамола в плазме крови: соотношения $\mathrm{S}-$ и R-сальбутамола при определении параметров $\mathrm{AUC}_{0-25 \text { мин и }}$ $\mathrm{C}_{\max }$ составили 1,25 и 1,14 соответственно.

Биотрансформация. Mohammed et al. (2000) в эксперименте на морских свинках с гистамин-индуцированной бронхоконстрикцией установили, что способ введения бронхолитика имеет критическое значение для получения персистирующего терапевтического действия. После однократного ингаляционного введения бронхолитический эффект сальбутамола (1 мг/кг) у животных сохранялся в течение одного часа, а в случае внутривенного введения - не более 30 минут. Пролонгирование терапевтического эффекта сальбутамола в случае его ингаляционной доставки, как минимум, отчасти может быть обусловлено снижением «потерь» фармакологически активной субстанции в ходе метаболизма в печени, а также менее интенсивной биотрансформацией ее в тканях респираторной системы. В рамках сравнительного исследования, про- водившегося Arroyo et al. (2016), у лошадей с рекуррентной обструкцией дыхательных путей в условиях ингаляционного введения с помощью небулайзера продолжительность бронходилатирующего действия сальбутамола составила 60 минут, левосальбутамола - 120 минут.

Eaton et al. (1996) изучили процесс сульфатирования сальбутамола и его энантиомеров в гомогенате клеток легких и бронхиальных эпителиоцитов (BEAS-2B) человека. Как оказалось, в легких внутренний клиренс $\left(\mathrm{V}_{\max } / \mathrm{K}_{\mathrm{m}}\right) \mathrm{R}$-сальбутамола почти в 11 раз превышает таковой для S-сальбутамола $(0,49 \pm$ 0,32 мл/мин·г протеина против 0,046 \pm 0,028 мл/мин·мг протеина), что обусловлено существенными различиями $\mathrm{K}_{\mathrm{m}}$, которые в 16 раз выше для S-энантиомера (1300 170 против $83 \pm 12$ мкмоль). Кинетика метаболизма энантиомеров сальбутамола в клетках BEAS-2B аналогична, хотя в целом интенсивность сульфатирования ниже. В то же время, по данным Nakpheng et al. (2017), in vitro в экстраклеточной среде, внутриклеточной жидкости и лизате клеток легочной ткани метаболиты сальбутамола не детектируются, а значение соотношения S/Rэнантиомеров во всех клеточных фракциях варьируют в пределах 0,99-1,10, независимо от фазы клеточного цикла и концентрации бронхолитика. Последнее указывает на отсутствие стереоселективного распределения и механизмов биотрансформации сальбутамола в легочной ткани.

В метаболизме сальбутамола главную роль играют цитозольные сульфотрансферазы (SULT), которые принадлежат семейству детоксицирующих энзимов II фазы и катализируют сульфатирование нативных и экзогенных гидрофобных молекул (Suiko et al., 2017). Флавоноиды могут выступать в качестве ингибиторов SULT1A1 и подавлять сульфатирование ксенобиотиков как в печени, так и в кишечнике, о чем следует иметь в виду в случае терапии сальбутамолом и левосальбутамолом с сопутствующим потреблением флавоноидсодержащих пищевых продуктов (De et al., 2000; Marchetti et al., 2001; De et al., 2002). Кверцетин ингибирует сульфатирование R-сальбутамола, причем интенсивность ингибиторного действия на один - два порядка выше в двенадцатиперстной кишке по сравнению с печенью (Pacifici, 2004). B результате S-сальбутамол более длительный период персистирует в организме и достигает значимо более высоких концентраций в плазме крови по сравнению с R-энантиомером (Sjöswärd et al., 2003). SULT1A3 относительно резистентен к ингибиторным эффектам мефенамовой кислоты, салициловой кислоты и кверцетина (Pacifici, 2004). Мефенамовая и салициловая кислоты также являются ингибиторами SULT1A1 (Vietri et al., 2001, 2002) и могут подавлять сульфатирование R-сальбутамола в печени (Vietri et al., 2000).

По данным Martin et al. (1971), ${ }^{3}$ Н-меченый сальбутамол подвергается быстрой гастроинтестинальной абсорбции у крыс, кроликов, собак и человека. При этом, в зависимости от вида, уровень радиоактивности в моче в течение 24 ч после однократного введения достигает 60-90\%, из которых 70-90\% у собак обусловлены неизмененным веществом, 90\% у кроликов и $40 \%$ у крыс ${ }^{3}$ Н-сальбутамол-о-фенилглюкуронидом, не обладающим $\beta_{2}$-агонистической или $\beta_{2}$-антагонистической активностью. У крыс глюкуронид ${ }^{3} \mathrm{H}$-сальбутамола, образуемый в печени, экскретируется также с желчью. Уровень экскреции глюкуронида с калом у крыс в течение 0-48 ч после введения может достигать 25-40\% от введенной дозы радиоактивно меченого бронхолитика. С учетом данных анализа распределения у крыс и собак сальбутамол подвергается полной экскреции из организма, не проявляя способности к кумуляции. В условиях ингаляционного введения в форме аэрозоля у собак и человека ${ }^{3}$ Н-меченый сальбутамол медленно абсорбируется в системный кровоток из тканей легких и в конечном итоге элиминируется с мочой.

Согласно экспериментальным данным Klaassen et al. (1998), уровень экспрессии мPHK SULT1A1 в печени половозрелых крыс, играющий ключевую роль в метаболизме простых фенолов у животных и человека, почти в два раза выше у самцов, 
чем у самок. Значимые различия уровня мPHK SULT1A1 обусловлены выраженным снижением ее экспрессии у самок после полового созревания. У животных обоего пола, подвергнутых гипофизэктомии, экспрессия мРНК снижается в равной степени, при этом заместительная терапия гормоном роста не ассоциируется с восстановлением экспрессии мPHK SULT1A1. Таким образом, приведенные данные могут указывать на наличие зависимости интенсивности метаболической биоконверсии сальбутамола от пола. Значимо более интенсивная экспрессия мPHK SULT1A1 у крыс-самцов регистрируется и в других тканях, включая головной мозг, легкие, сердце, кишечник, почки, надпочечники, тестикулы и селезенку. Интересно, что у крыссамцов, подвергнутых парциальной гепатэктомии, отмечалась лишь тенденция к некоторому снижению экспрессии мРНК SULT1A1, сходная с изменениями регистрировавшимися в экспериментах с применением других быстро пролиферирующих тканей (в частности, злокачественных опухолей и тканей неполовозрелых животных) (Dunn et al., 1999).

Хиральная инверсия. Нередко при применении энантиомерно чистых субстанций в организме происходит их хиральная инверсия в соответствующие дистомеры, не только проявляющие иной фармакокинетический и фармакодинамический профиль, но и несущие токсический потенциал. Красноречивым примером хиральной инверсии и ее потенциально неблагоприятного клинического значения у человека является талидомид, энантиомеры которого быстро подвергаются рацемизации in vivo и ассоциируются с хорошо известными тератогенными эффектами талидомида (Zhou et al., 2015).

Ko et al. (2012) в эксперименте in vitro с применением культуры клеток гепатомы человека HepG2 подтвердили роль сульфатирования в печени как основного механизма биотрансформации сальбутамола у человека, оценивавшегося по интенсивности генерации ${ }^{35}$ S-меченого сульфата. В ходе тестирования специфической активности 11 рекомбинантных изоформ SULT человека установлено, что SULT1A3 играет преференциальную роль в метаболизме и детоксикации сальбутамола. При этом сальбутамол оказывает концентрацие-зависимое ингибирование метаболизма дофамина. По мнению исследователей, в высоких дозах сальбутамол может интерферировать с гомеостазом дофамина и, возможно, других катехоламинов in vivo. В эксперименте с применением цитозольных и $\mathrm{S}_{9}$ фракций, полученных из образцов тканей легких, печени, почек и сегмента тонкого кишечника человека, установлено, что скорость интестинальной биотрансформации максимальна по сравнению со скоростью в других тканях.

Ранее установлено, что при ингаляционном введении у собак и человека феномен взаимной хиральной инверсии энантиомеров для сальбутамола не характерен (Fried et al., 1998; Auclair et al., 2000). В то же время, по данным Boulton and Fawcett (2001), после перорального или ингаляционного введения энантиомерно чистого сальбутамола около 6\% вещества подвергается конверсии в другой энантиомер, что, как предполагается, связано с рацемизацией, катализируемой кислой средой в желудке.

Экскреция. У кроликов после перорального и ректального введения общий уровень экскреции сальбутамола и его глюкуронида с мочой по прошествии 10 ч после введения составляет около $77 \%$ и 10\%, соответственно (Kurosawa et al., 1993).

\section{Выводы}

Данные доклинических исследований указывают на преимущества R-энантиомера сальбутамола перед рацемическим сальбутамолом и его S-изомером. Это проявляется в значительно большем аффинитете (в 90-100 раз) левосальбутамола в отношении $\beta_{1}$ - и $\beta_{2}$-адренорецепторов по сравнению с его дистомером. При этом эффективность левосальбутамола эквивалентна таковой у сальбутамола, в то время как продолжительность действия энантиомерно чистой субстанции R-сальбутамола как минимум в два раза выше по сравнению с рацематом.
Для R-сальбутамола не характерен феномен развития гиперреактивности дыхательных путей, который может развиваться при применении рацемического сальбутамола. Важно обратить внимание на то, что главную роль в аномальном, на первый взгляд, увеличении тонуса бронхов играет S-энантиомер сальбутамола. Важная способность рацемического сальбутамола - увеличивать мукоцилиарный клиренс - у левосальбутамола выражена практически в два раза сильнее. Это свидетельствует о том, что позитивные эффекты рацемического сальбутамола на мукоцилиарный клиренс обусловлены присутствием в его составе R-энантиомера. Левосальбутамол, в отличие от дистомера, способен оказывать противовоспалительное действие, которое выражается в уменьшении количества эозинофилов и нейтрофилов в бронхоальвеолярном лаваже, уровня полимофоядерных клеток в бронхоальвеолярной жидкости и ряда цитокинов, включая CXCL1, MCP-1 (CCL2), TNF- $\alpha$, играющих ключевую роль в патогенезе острого легочного IgG-индуцированного повреждения. R-сальбутамол способен подавлять гиперплазию гоблетовских клеток и слизистую окклюзию дыхательных путей, а также уменьшать уровни IL-4 в бронхоальвеолярном лаваже и овальбумин-специфического IgE в плазме крови экспериментальных животных. В свою очередь, S-сальбутамол проявляет противоположные свойства и способен усиливать воспалительную реакцию.

В связи с тем, что рацемический сальбутамол подвергается стереоселективному метаболизму с активным сульфатированием R-изомера и закономерным накоплением токсичного дистомера в организме, видится разумным применение гомохирального ингаляционного препарата на основе левосальбутамола. Таким образом, гомохиральные препараты на основе $\mathrm{R}$-сальбутамола (левосальбутамола) могут быть более эффективными и безопасными в качестве бронхолитиков в сравнении с рацематом.

Работа выполнена в ФГБОУ ВО «Алтайский государственный университет» в рамках комплексного проекта «Создание высокотехнологичного производства жизненно важного лекарственного противоастматического препарата «Сальбутамол» в аэрозольной форме на основе энантиомерно чистой, микронизированной субстанции, получаемой с помощью сверхкритических флюидных технологий» (договор № 03.G25.31.0273 от 29 мая 2017 г.).

\section{References}

Agrawal, D., Ariyarathna, K., \& Kelbe, P. (2004). S-Albuterol activates proconstrictory and pro-inflammatory pathways in human bronchial smooth muscle cells. Journal of Allergy and Clinical Immunology, 113(3), 503-510.

Ameredes, B. T., \& Calhoun, W. J. (2006). R-Albuterol for asthma: Pro [a.k.a. SAlbuterol for Asthma: Con]. American Journal of Respiratory and Critical Care Medicine, 174, 965-974.

Ameredes, B. T., \& Calhoun, W. J. (2010). Albuterol enantiomers: Pre-clinical and clinical value? Frontiers in Bioscience (Elite Edition), 2, 1081-1092.

Angulo, M., Taranto, E., Soto, J. P., Malacrida, L., Nin, N., Hurtado, F. J., \& Píriz, H. (2009). Salbutamol improves diaphragmatic contractility in chronic airway obstruction. Archivos de Bronconeumología, 45(5), 230-234.

Arrowsmith, J. (2011). Trial watch: Phase II failures: 2008-2010. Nature Reviews Drug Discovery, 10(5), 328-329.

Arrowsmith, J. (2011). Trial watch: Phase III and submission failures: 2007-2010. Nature Reviews Drug Discovery, 10(2), 87.

Arroyo, M., Couëtil, L., Nogradi, N., Kamarudin, M., \& Ivester, K. (2016). Efficacy of inhaled levalbuterol compared to albuterol in horses with recurrent airway obstruction. Joumal of Veterinary Internal Medicine, 30(4), 1333-1337.

Auais, A., Wedde-Beer, K., \& Piedimonte, G. (2005). Anti-inflammatory effect of albuterol enantiomers during respiratory syncytial virus infection in rats. Pediatric Pulmonology, 40(3), 228-234.

Auclair, B., Wainer, I., Fried, K., Koch, P., Jerussi, T., \& Ducharme, M. (2000). A population analysis of nebulized (R)-albuterol in dogs using a novel mixed gut-lung absorption PK-PD model. Pharmaceutical Research, 17(10), 12281235.

Bae, R., Arteaga, A., Raj, J., \& Ibe, B. (2012). Albuterol isomers modulate platelet-activating factor synthesis and receptor signaling in human bronchial 
smooth muscle cells. International Archives of Allergy and Immunology, 158(1), 18-26.

Baramki, D., Koester, J., Anderson, A., \& Borish, L. (2002). Modulation of T-cel function by R- and S-isomers of albuterol: Anti-inflammatory influences of $\mathrm{R}$-isomers are negated in the presence of the S-isomer. The Journal of Allergy and Clinical Immunology, 109(3), 449-454.

Barnette, D., Johnson, B., Pouncey, D., Nshimiyimana, R., Desrochers, L., Goodwin, T., \& Miller, G. (2017). Stereospecific metabolism of R- and Swarfarin by human hepatic cytosolic reductases. Drug Metabolism and Disposition, 45(9), 1000-1007.

Berger, W. E. (2003). Levalbuterol: Pharmacologic properties and use in the treatment of pediatric and adult asthma. Annals of Allergy, Asthma and Immunology, 90(6), 583-591.

Blin, O. (2004). Chiral switch: Towards a better benefit-risk ratio? Therapie, 59(6), 625-628.

Bosak, A., Knežević, A., Gazić, S. I., Šinko, G., \& Kovarik, Z. (2017). Resorcinol, catechol- and saligenin-based bronchodilating $\beta_{2}$-agonists as inhibitors of human cholinesterase activity. Journal of Enzyme Inhibition and Medicinal Chemistry, 32(1), 789-797.

Boskabady, M. H., \& Aslani, M. R. (2007). Influence of epithelium on $\beta$-adrenoceptor desensitization of guinea pig tracheal smooth muscle. Respiratory Physiology and Neurobiology, 156(1), 69-78.

Bosmann, M., Grailer, J., Zhu, K., Matthay, M., Sarma, J., Zetoune, F., \& Ward, P. (2012). Anti-inflammatory effects of $\beta_{2}$ adrenergic receptor agonists in experimental acute lung injury. The FASEB Journal, 26(5), 2137-2144.

Boulton, D. W., \& Fawcett, J. P. (2001). The pharmacokinetics of levosalbutamol: What are the clinical implications? Clinical Pharmacokinetics, 40(1), 23-40.

Boulton, D. W., \& Fawcett, J. P. (2002). B 2 -agonist eutomers: A rational option for the treatment of asthma? American Journal of Respiratory Medicine, 1(5), 305-311.

Broadley, K. J. (2006). B-adrenoceptor responses of the airways: For better or worse? European Journal of Pharmacology, 533(1-3), 15-27.

Buchheit, K. H., Hofmann, A., \& Fozard, J. R. (1995). Salbutamol-induced airway hyperreactivity in guinea pigs is not due to a loss of its bronchodilator effect. European Journal of Pharmacology, 287(1), 85-88.

Burke, D., \& Henderson, D. J. (2002). Chirality: A blueprint for the future. British Journal of Anaesthesia, 88(4), 563-576.

Calcaterra, A., \& D’Acquarica, I. (2017). The market of chiral drugs: Chiral switches versus de novo enantiomerically pure compounds. Journal of Pharmaceutical and Biomedical Analysis, S0731-7085(17), 31483-31488.

Cazzola, M., Page, C., Calzetta, L., \& Matera, G. (2012). Pharmacology and therapeutics of bronchodilators. Pharmacological Reviews, 64, 450-504.

Chong, L., Suvarna, K., Chess-Williams, R., \& Peachell, P. (2003). Desensitization of $\beta_{2}$-adrenoceptor-mediated responses by short-acting $\beta_{2}$-adrenoceptor agonists in human lung mast cells. British Journal of Pharmacology, 138(3), 512-520.

Chorley, B., Li, Y., Fang, S., Park, J., \& Adler, K. (2006). R-albuterol elicits antiinflammatory effects in human airway epithelial cells via iNOS. American Journal of Respiratory Cell and Molecular Biology, 34(1), 119-127.

Cockcroft, D., Davis, B., Swystun, V., \& Marciniuk, D. (1999). Tolerance to the bronchoprotective effect of $\beta_{2}$-agonists: Comparison of the enantiomers of salbutamol with racemic salbutamol and placebo. The Journal of Allergy and Clinical Immunology, 103(6), 1049-1053.

Cooper, P. R., \& Panettieri, R. A. Jr. (2008). Steroids completely reverse albuterolinduced $\beta(2)$-adrenergic receptor tolerance in human small airways. The Journal of Allergy and Clinical Immunology, 122(4), 734-740.

Cooper, P., Kurten, R., Zhang, J., Nicholls, D., Dainty, I., \& Panettieri, R. (2011) Formoterol and salmeterol induce a similar degree of $\beta_{2}$-adrenoceptor tolerance in human small airways but via different mechanisms. British Journal of Pharmacology, 163(3), 521-532.

Costello, J. (1999). Prospects for improved therapy in chronic obstructive pulmonary disease by the use of levalbuterol. The Journal of Allergy and Clinical Immunology, 104(2Pt2), S61-68.

De Santi, C., Pietrabissa, A., Mosca, F., Rane, A., \& Pacifici, G. M. (2002). Inhibition of phenol sulfotransferase (SULT1A1) by quercetin in human adult and foetal livers. Xenobiotica, 32(5), 363-368.

De Santi, C., Pietrabissa, A., Spisni, R., Mosca, F., \& Pacifici, G. (2000). Sulphation of resveratrol, a natural compound present in wine, and its inhibition by natural flavonoids. Xenobiotica, 30(9), 857-866.

Delmotte, P., \& Sanderson, M. J. (2008). Effects of albuterol isomers on the contraction and $\mathrm{Ca}^{2+}$ signaling of small airways in mouse lung slices. American Journal of Respiratory Cell and Molecular Biology, 38, 524-531.

Derom, E., Gayan-Ramirez, G., Gurrieri, G., de Bock, V., \& Decramer, M. (1997). Broxaterol increases force output of fatigued canine diaphragm more than salbutamol. American Journal of Respiratory and Critical Care Medicine, 155(1), 181-185.
Duffy, S., Cruse, G., Lawley, W., \& Bradding, P. (2005). $\beta_{2}$-adrenoceptor regulation of the $\mathrm{K}^{+}$channel iKCa1 in human mast cells. The FASEB Journal, 19(8), 1006-1008.

Dunn, R., Kolaja, K., \& Klaassen, C. (1999). Effect of partial hepatectomy on the expression of seven rat sulphotransferase mRNAs. Xenobiotica, 29(6), 583593.

Eaton, E., Walle, U., Wilson, H., Aberg, G., \& Walle, T. (1996). Stereoselective sulphate conjugation of salbutamol by human lung and bronchial epithelial cells. British Journal of Clinical Pharmacology, 41(3), 201-206.

Esau, S. A. (1989). Hypoxic, hypercapnic acidosis decreases tension and increases fatigue in hamster diaphragm muscle in vitro. The American Review of Respiratory Disease, 139(6), 1410-1417.

Ferrada, M., Gordon, E., Jen, K., He, H., Lu, X., Barone, L., \& Finn, P. W. (2008) (R)-albuterol decreases immune responses: Role of activated T cells. Respiratory Research, 9(1), 3

Fried, K., Koch, P., \& Wainer, I. (1998). Determination of the enantiomers of albuterol in human and canine plasma by enantioselective high-performance liquid chromatography on a teicoplanin-based chiral stationary phase. Chirality, 10(5), 484-491.

Frieri, M., \& Capetandes, A. (2008). The effect of enantiomers of $\beta$-agonists on myofibroblast-derived vascular endothelial growth factor and other matrix components in the presence of dust-mite extract. Allergy and Asthma Proceedings, 29(2), 182-188.

Frohock, J., Wijkstrom-Frei, C., \& Salathe, M. (2002). Effects of albutero enantiomers on ciliary beat frequency in ovine tracheal epithelial cells. Journal of Applied Physiology, 92(6), 2396-2402.

Gashaw, I., Ellinghaus, P., Sommer, A., \& Asadullah, K. (2012). What makes a good drug target? Drug Discovery Today, 17(Suppl.), S24-30.

Gaskell, H., Derry, S., Wiffen, P., \& Moore, R. (2017). Single dose ora ketoprofen or dexketoprofen for acute postoperative pain in adults. The Cochrane Database of Systematic Reviews (CD007355).

Günay, S., Sarıydın, M., \& Yilmaz, D. N. (2016). New bronchodilators and combinations in COPD treatment. Tuberkuloz Ve Toraks, 64(3), 240-245.

Gutierrez-Climente, R., Gomez-Caballero, A., Guerreiro, A., Garcia-Mutio, D. Unceta, N., Goicolea, M., \& Barrio, R. (2017). Molecularly imprinted nanoparticles grafted to porous silica as chiral selectors in liquid chromatography. Journal of Chromatography A, 1508, 53-64.

Handley, D. (1999). The asthma-like pharmacology and toxicology of S-isomers of $\beta$ agonists. The Journal of Allergy and Clinical Immunology, 104(2Pt2), S69-76.

Handley, D. A., Morley, J., \& Vaickus, L. (1998). Levalbuterol hydrochloride. Expert opinion on investigational drugs, 7(12), 2027-2041.

Handley, D., McCullough, J., Crowther, S., \& Morley, J. (1998). Sympathomimetic enantiomers and asthma. Chirality, 10(3), 262-272.

Hauck, R., Harth, M., Schulz, C., Präuer, H., Böhm, M., \& Schömig, A. (1997). Effects of $\beta_{2}$-agonist- and dexamethasone-treatment on relaxation and regulation of $\beta$-adrenoceptors in human bronchi and lung tissue. British Journal of Pharmacology, 121(8), 1523-1530.

Henderson, W., Banerjee, E., \& Chi, E. (2005). Differential effects of S- and Renantiomers of albuterol in a mouse asthma model. The Journal of Allergy and Clinical Immunology, 116(2), 332-340.

Herepath, M. L., \& Broadley, K. J. (1992). Resistance of $\beta_{2}$-adrenoceptormediated responses of lung strips to desensitization by long-term agonis exposure-comparison with atrial $\beta_{1}$-adrenoceptor-mediated responses. European Journal of Pharmacology, 215(2-3), 209-219.

Honda, Z., Ishii, S., \& Shimizu, T. (2002). Platelet-activating factor receptor Journal of Biochemistry, 131(6), 773-779.

Ibe, B. O., Abdallah, M. F., \& Raj, J. U. (2008). Mechanisms by which Salbuterol induces human bronchial smooth muscle cell proliferation. International Archives of Allergy and Immunology, 146(4), 321-333.

Ibe, B., Portugal, A., \& Raj, J. (2006). Levalbuterol inhibits human airway smooth muscle cell proliferation: Therapeutic implications in the management of asthma. International Archives of Allergy and Immunology, 139(3), 225-236.

Ito, T., Fujimura, N., Omote, K, \& Namiki, A (2006). A selective $\beta_{2}$-adrenergic agonist, terbutaline, improves sepsis-induced diaphragmatic dysfunction in the rat. Life Sciences, 79(9), 905-912.

Jacobson, G., Raidal, S., Robson, K., Narkowicz, C., Nichols, D., \& Haydn, W. E. (2017). Bronchopulmonary pharmacokinetics of R-salbutamol and Ssalbutamol enantiomers in pulmonary epithelial lining fluid and lung tissue of horses. British Journal of Clinical Pharmacology, 83(7), 1436-1445.

Jantikar, A., Brashier, B., Maganji, M., Raghupathy, A., Mahadik, P., Gokhale, P., \& Salvi, S. (2007). Comparison of bronchodilator responses of levosalbutamol and salbutamol given via a pressurized metered dose inhaler: A randomized, double blind, single-dose, crossover study. Respiratory Medicine, 101(4), 845-849.

Javaheri, S., Smith, J., Thomas, J., Guilfoile, T., \& Donovan, E. (1988). Albutero has no effect on diaphragmatic fatigue in humans. The American Review of Respiratory Disease, 137(1), 197-201. 
Keir, S., Page, C., \& Spina, D. (2002). Bronchial hyperresponsiveness induced by chronic treatment with albuterol: Role of sensory nerves. The Journal of Allergy and Clinical Immunology, 110(3), 388-394.

Klaassen, C., Liu, L., \& Dunn, R. (1998). Regulation of sulfotransferase mRNA expression in male and female rats of various ages. Chemico-Biological Interactions, 109, 299-313.

Ko, K., Kurogi, K., Davidson, G., Liu, M., Sakakibara, Y., Suiko, M., \& Liu, M (2012). Sulfation of ractopamine and salbutamol by the human cytosolic sulfotransferases. Journal of Biochemistry, 152(3), 275-283.

Kubinyi, H. (2002). Chemical similarity and biological activities. Journal of the Brazilian Chemical Society, 13(6), 717-726.

Kuchay, M. S., \& Mithal, A. (2017). Levosulpiride and serum prolactin levels. Indian Journal of Endocrinology and Metabolism, 21(2), 355

Kurosawa, N., Morishima, S., Owada, E., \& Ito, K. (1993). Comparison of bioavailability of salbutamol between oral and rectal administration in rabbits. Yakugaku Zasshi: Journal of the Pharmaceutical Society of Japan, 113(4), 321-326

Kurosawa, N., Owada, E., \& Ito, K. (1993). Absorption and first-pass-effect of salbutamol after intraduodenal and intrarectal administration in rabbits. Yakugaku Zasshi: Journal of the Pharmaceutical Society of Japan, 113(10), 698-704.

Lemoine, H., Overlack, C., Köhl, A., Worth, H., \& Reinhardt, D. (1992). Formoterol, fenoterol, and salbutamol as partial agonists for relaxation of maximally contracted guinea pig tracheae: Comparison of relaxation with receptor binding. Lung, 170(3), 163-180.

Li, L., Cheng, B., Zhou, R., Cao, Z., Zeng, C., \& Li, L. (2017). Preparation and evaluation of a novel N-benzyl-phenethylamino- $\beta$-cyclodextrin-bonded chiral stationary phase for HPLC. Talanta, 174, 179-191.

Li, L., Wu, C., Ma, Y., Zhou, S., Li, Z., \& Sun, T. (2017). Effectively enhancing the enantioseparation ability of $\beta$-cyclodextrin derivatives by de novo design and molecular modeling. Analyst, 142(19), 3699-3706.

Liu, Y., Deng, M., Yu, J., Jiang, Z., \& Guo, X. (2016). Capillary electrophoretic enantioseparation of basic drugs using a new single-isomer cyclodextrin derivative and theoretical study of the chiral recognition mechanism. Journal of Separation Science, 39(9), 1766-1775.

Marchetti, F., De, S. C., Vietri, M., Pietrabissa, A., Spisni, R., Mosca, F. (2001) Differential inhibition of human liver and duodenum sulphotransferase activities by quercetin, a flavonoid present in vegetables, fruit and wine. Xenobiotica, 31(12), 841-847.

Martin, L., Hobson, J., Page, J., \& Harrison, C. (1971). Metabolic studies of salbutamol-3H: A new bronchodilator, in rat, rabbit, dog and man. European Journal of Pharmacology, 14(2), 183-199.

Matera, M., Calzetta, L., Rogliani, P., Bardaro, F., Page, C., \& Cazzola, M. (2011). Evaluation of the effects of the R- and S-enantiomers of salbutamol on equine isolated bronchi. Pulmonary Pharmacology and Therapeutics, 24(2), 221-226.

Mazzoni, L., Naef, R., Chapman, I., \& Morley, J. (1994). Hyperresponsiveness of the airways following exposure of guinea-pigs to racemic mixtures and distomers of $\beta_{2}$-selective sympathomimetics. Pulmonary Pharmacology and Therapeutics, 7(6), 367-376

McAuley, D., Frank, J., Fang, X., \& Matthay, M. (2004). Clinically relevant concentrations of $\beta_{2}$-adrenergic agonists stimulate maximal cyclic adenosine monophosphate-dependent airspace fluid clearance and decrease pulmonary edema in experimental acid-induced lung injury. Critical Care Medicine, 32(7), 1470-1476

Milgrom, H. (2006). Levosalbutamol in the treatment of asthma. Expert Opinion on Pharmacotherapy, 7(12), 1659-1668.

Mitra, S., Ugur, M., Ugur, O., Goodman, H., McCullough, J., \& Yamaguchi, H. (1998). S-Albuterol increases intracellular free calcium by muscarinic receptor activation and a phospholipase C-dependent mechanism in airway smooth muscle. Molecular Pharmacology, 53(3), 347-354.

Mohammed, S. P., Taylor, C. V., Weyman-Jones, C. B., Mather, M. E., Vendy, K., Dougall, I. G., \& Young, A. (2000). Duration of action of inhaled vs. intravenous $\beta_{2}$-adrenoceptor agonists in an anaesthetized guinea-pig model. Pulmonary Pharmacology and Therapeutics, 13(6), 287-292.

Momose, T., Okubo, Y., Horie, S., Suzuki, J., Isobe, M., \& Sekiguchi, M. (1998). Effects of intracellular cyclic AMP modulators on human eosinophil survival, degranulation and CD11b expression. International Archives of Allergy and Immunology, 117(2), 138-145.

Nakpheng, T., Songkarak, S., Suwandecha, T., Sritharadol, R., Chunhachaichana C., \& Srichana, T. (2017). Evidences for salbutamol metabolism by respiratory and liver cell lines. Drug Metabolism and Pharmacokinetics, 32(2), 127-134.

Nelson, H. S. (1999). Clinical experience with levalbuterol. The Journal of Allergy and Clinical Immunology, 104(2Pt2), S77-84.

Noguchi, S., Nishimura, T., Mukaida, S., Benet, L., Nakashima, E., \& Tomi, M. (2017). Cellular uptake of levocetirizine by organic anion transporter 4 Journal of Pharmaceutical Sciences, 106(9), 2895-2898.
Nowak, R. (2003). Single-isomer levalbuterol: A review of the acute data. Current Allergy and Asthma Reports, 3(2), 172-178.

Pacifici, G. M. (2004). Inhibition of human liver and duodenum sulfotransferases by drugs and dietary chemicals: A review of the literature. International Journal of Clinical Pharmacology and Therapeutics, 42(9), 488-495.

Page, C. P., \& Morley, J. (1999). Contrasting properties of albuterol stereoisomers. The Journal of Allergy and Clinical Immunology, 104(2Pt2), S31-41.

Penn, R., Frielle, T., McCullough, J., Aberg, G., \& Benovic, J. (1996) Comparison of R-, S-, and RS-albuterol interaction with human $\beta_{1^{-}}$and $\beta_{2^{-}}$ adrenergic receptors. Clinical Reviews in Allergy and Immunology, 14(1), $37-45$.

Píriz, H., Nin, N., Boggia, J., Angulo, M., \& Hurtado, F. J. (2008). Salbutamol improves diaphragm force generation in experimental sepsis. Archivos de Bronconeumología (English Edition), 44(3), 135-139.

Reinero, C., Delgado, C., Spinka, C., DeClue, A., \& Dhand, R. (2009). Enantiomer-specific effects of albuterol on airway inflammation in healthy and asthmatic cats. International Archives of Allergy and Immunology, 150(1), 43-50

Roth, M., Nauck, M., Yousefi, S., Tamm, M., Blaser, K., Perruchoud, A. (1996). Platelet-activating factor exerts mitogenic activity and stimulates expression of interleukin 6 and interleukin 8 in human lung fibroblasts via binding to its functional receptor. The Journal of Experimental Medicine, 184(1), 191-201.

Sabater, J., Lee, T., \& Abraham, W. (2005). Comparative effects of salmeterol, albuterol, and ipratropium on normal and impaired mucociliary function in sheep. Chest, 128(5), 3743-3749.

Sardella, R., Ianni, F., Di Michele, A., Di Capua, A., Carotti, A., Anzini, M., \& Natalini, B. (2017). Enantioresolution and stereochemical characterization of two chiral sulfoxides endowed with COX-2 inhibitory activity. Chirality, 29(9), 536-540.

Scola, A., Chong, L., Suvarna, S., Chess-Williams, R., \& Peachell, P. (2004). Desensitisation of mast cell $\beta_{2}$-adrenoceptor-mediated responses by salmetero and formoterol. British Journal of Pharmacology, 141(1), 163-171.

Shen, Q., Wang, L., Zhou, H., Jiang, H., Yu, L., \& Zeng, S. (2013). Stereoselective binding of chiral drugs to plasma proteins. Acta Pharmacologica Sinica, 34(8), 998-1006

Sjöswärd, K. N., Josefsson, M., Ahlner, J., Andersson, R. G., \& Schmekel, B. (2003) Metabolism of salbutamol differs between asthmatic patients and healthy volunteers. Basic and Clinical Pharmacology and Toxicology, 92(1), 27-32.

Soriano-Ursúa, M., Trujillo-Ferrara, J, Alvarez-Cedillo, J, \& Correa-Basurto, J. (2010). Docking studies on a refined human $\beta(2)$ adrenoceptor model yield theoretical affinity values in function with experimental values for R-ligands, but not for S-antagonists. Journal of Molecular Modeling, 16(3), 401-409.

Stank, A., Kokh, D., Fuller, J., \& Wade, R. (2016). Protein binding pocket dynamics. Accounts of Chemical Research, 49(5), 809-815.

Suiko, M., Kurogi, K., Hashiguchi, T., Sakakibara, Y., \& Liu, M. (2017). Updated perspectives on the cytosolic sulfotransferases (SULTs) and SULT-mediated sulfation. Bioscience, Biotechnology, and Biochemistry, 81(1), 63-72.

Theron, A., Steel, H., Tintinger, G., Feldman, C., \& Anderson, R. (2013). Can the anti-inflammatory activities of $\beta_{2}$-agonists be harnessed in the clinical setting? Drug Design, Development and Therapy, 7, 1387-1398.

Tran, T., Friedman, J., Qunaibi, E., Baameur, F., Moore, R., \& Clark, R. (2004). Characterization of agonist stimulation of cAMP-dependent protein kinase and $G$ protein-coupled receptor kinase phosphorylation of the $\beta_{2}$-adrenergic receptor using phosphoserine-specific antibodies. Molecular Pharmacology, 65(1), 196-206.

Uzuki, M., Yamakage, M., Fujimura, N., \& Namiki, A. (2006). Preferable inotropic action of procaterol, a potent bronchodilator, on impaired diaphragmatic contractility in an intraabdominal septic model. Journal of Anesthesia, 20(2), 145-148.

Uzuki, M., Yamakage, M., Fujimura, N., \& Namiki, A. (2007). Direct inotropic effect of the $\beta-2$ receptor agonist terbutaline on impaired diaphragmatic contractility in septic rats. Heart and Lung: The Journal of Acute and Critical Care, 36(2), 140-147

Välitalo, P. A., Kemppainen, H., Kulo, A, Smits, A., Calsteren, K., Olkkola, K. T., \& Allegaert, K. (2017). Body weight, gender and pregnancy affect enantiomer - specific ketorolac pharmacokinetics. British Journal of Clinical Pharmacology, 83(9), 1966-1975.

Van der Heijden, H., Dekhuijzen, P., Folgering, H., \& van Herwaarden, C. (1997) Inotropic effects of salbutamol on rat diaphragm contractility are potentiated by foreshortening. American Joumal of Respiratory and Critical Care Medicine, 155(3), 1072-1079.

Vietri, M., Pietrabissa, A., Mosca, F., Rane, A., \& Pacific, G. (2001). Human adult and foetal liver sulphotransferases: Inhibition by mefenamic acid and salicylic acid. Xenobiotica, 31(3), 153-161.

Vietri, M., Pietrabissa, A., Spisni, R., Mosca, F., \& Pacifici, G. (2000). Differential inhibition of hepatic and duodenal sulfation of (-)-salbutamol and minoxidi by mefenamic acid. European Journal of Clinical Pharmacology, 56(5-6), 477-479. 
Vietri, M., Vaglini, F., Pietrabissa, A., Spisni, R., Mosca, F., \& Pacifici, G. (2002). Sulfation of R(-)-apomorphine in the human liver and duodenum, and its inhibition by mefenamic acid, salicylic acid and quercetin. Xenobiotica, 32(7), 587-594.

Volcheck, G., Kelkar, P., Bartemes, K., Gleich, G., \& Kita, H. (2005). Effects of $\mathrm{R}$ - and S-isomers of $\beta$-adrenergic agonists on eosinophil response to interleukin-5. Clinical and Experimental Allergy, 35(10), 1341-1346.

Wang, X. S., \& Lau, H. Y. (2006). $\beta$-adrenoceptor-mediated inhibition of mediator release from human peripheral blood-derived mast cells. Clinical and Experimental Pharmacology and Physiology, 33(8), 746-750.

Westerhof, F., Zuidhof, A., Kok, L., Meurs, H., \& Zaagsma, J. (2005). Effects of salbutamol and enantiomers on allergen-induced asthmatic reactions and airway hyperreactivity. European Respiratory Journal, 25, 864-872.
Xu, X., Zhou, J., Yang, Q., Fang, L., Xie, Q., \& Shen, Y. (2006). An in vitro rat diaphragmatic fatigue model induced by combined hypoxic and hypercapnic acidosis and the effect of salmeterol. Pharmacological Research, 53(2), 171-176.

Yao, Y., Song, P., Wen, X., Deng, M., Wang, J., \& Guo, X. (2017). Chiral separation of 12 pairs of enantiomers by capillary electrophoresis using heptakis-(2,3-diacetyl-6-sulfato)- $\beta$-cyclodextrin as the chiral selector and the elucidation of the chiral recognition mechanism by computational methods. Journal of Separation Science, 40(14), 2999-3007.

Zhang, Y., Wu, D., Wang-Iverson, D., \& Tymiak, A. (2005). Enantioselective chromatography in drug discovery. Drug Discovery Today, 10(8), 571-577.

Zhou, T., Zeng, J., Liu, S., Zhao, T., Wu, J., Lai, W. (2015). Study on the determination and chiral inversion of R-salbutamol in human plasma and urine by liquid chromatography-tandem mass spectrometry. Journal of Chromatography. B, Analytical Technologies in the Biomedical and Life Sciences, 1002, 218-227. 